\title{
APLYSFISTULARINE: A NOVEL DIBROMOTYROSINE DERIVATIVE ISOLATED FROM Aplysina fistularis"
}

Narlize Silva Lira, Rubens L. Monte-Neto, João Guilherme B. Marchi, Antônio Cláudio da Silva Lins, Josean Fechine Tavares, Marcelo Sobral da Silva, Celidarque da Silva Dias e José Maria Barbosa-Filho*

Departamento de Ciências Farmacêuticas, Universidade Federal da Paraíba, 58051-900 João Pessoa - PB, Brasil

Creusioni Figueredo dos Santos

Departamento de Biologia Molecular, Universidade Federal da Paraíba, 58051-900 João Pessoa - PB, Brasil

Emídio Vasconcelos Leitão da Cunha

Departamento de Farmácia, Universidade Estadual da Paraíba, 58100-000 Campina Grande - PB, Brasil

Ulisses dos Santos Pinheiro

Departamento de Zoologia, Universidade Federal de Pernambuco, 50373-970 Recife - PE, Brasil

Raimundo Braz-Filho

Centro de Ciências e Tecnologia, Universidade Estadual do Norte Fluminense, 28013-600 Campos dos Gaytacazes - RJ, Brasil

Recebido em 7/3/12; aceito em 31/7/12; publicado na web em 15/10/12

\begin{abstract}
The new dibromotyrosine derivative 3,5-dibromo-4-[3'dimethylamonium]propoxyphenyl]- $N, N, N$-trimethylethanamonium, here referred to as aplysfistularine (1), was isolated from the marine sponge Aplysina fistularis along with 2-(3,5-dibromo-4methoxyphenyl)- $N, N, N$-trimethylethanamonium (2), aplysterol (3) and 24,28-didehydroaplysterol (4). Their identification was performed by mass spectrometry, infrared, ${ }^{1} \mathrm{H}$ and ${ }^{13} \mathrm{C}$ NMR, and by comparison with literature data. Compound 2 and the mixture of 3 and 4 were tested in vitro (inhibitory activity) with supercoiled DNA relaxation techniques, and showed inhibitory activity on human DNA topoisomerase II- $\alpha$. Compound 1 was not tested due to paucity of the material.
\end{abstract}

Keywords: Aplysina fistularis; aplysfistularine; topoisomerase activity.

\section{INTRODUCTION}

A review of recent research reveals that the quest for new drugs is changing direction. Given the ever growing number of natural marine products discovered, researchers have recognized the promising potential of the sea for the chemistry of natural products. ${ }^{1-3}$ Despite the obstacles to effective development of marine organism-derived pharmaceutical agents, the interest in marine organisms as a new drug source has increased in recent years. ${ }^{4-10}$ Marine sponges are a prolific source of a huge variety of secondary metabolites. ${ }^{11-15}$ Sponges of the order Verongida, and the family Aplysinidae, characterized by the absence of terpenes and the production of steroids, produce a wide diversity of bromotyrosine-containing metabolites with interesting biological properties. ${ }^{16}$ The richest sources of biogenetically, tyrosine-derived bromo-containing amines, are members of the Verongida order, and the genus Aplysina. ${ }^{17-20}$ Previous and recent reports of Aplysina fistularis have documented the presence of a large number of brominated metabolites including: fistularines, aerothionines, ceratinamines, aplysamines, anamonianes and psammaplysines. ${ }^{21-23}$ The diversity of biological activity found in compounds isolated from marine sponges is due to the presence of bromotyrosine derivatives. In the case of the order Verongida, many of the species produce compounds with antimicrobial, antibacterial, cytotoxic and antitumor activity. ${ }^{23,24}$

Nuclear enzymes that control and modify the topological states of DNA are known as topoisomerases. In mammalian cells, they are classified into types I and II, according to their mechanisms and physical properties. Topoisomerase II (Topo II), a dimer composed of or isoforms with a total size of $170 \mathrm{KDa}$, is responsible for separating the double DNA helix, leading to events such as DNA release, transcription,

*e-mail: jbarbosa@ltf.ufpb.br

\#Artigo em homenagem ao Prof. Otto R. Gottlieb (31/8/1920-19/6/2011) chromosome condensation and recombination..$^{25-28}$ During cell proliferation, topoisomerases take part in DNA maintenance and replication. When these functions are deactivated, cells become vulnerable. Furthermore, the expression of DNA Topo I and II is higher in tumors than in normal cells. ${ }^{29}$ Topoisomerase II inhibitors with anticancer and antiviral potential are important targets in the development of new drugs ${ }^{30}$ In an attempt to discover new topoisomerase inhibitors, many classes of natural products have been tested and described in the literature, including flavonoids, ${ }^{31}$ biflavonoids, ${ }^{32}$ diterpenes, ${ }^{33}$ triterpenoids, ${ }^{34}$ estilbenoids, ${ }^{35}$ alkaloids, ${ }^{36-39}$ naphtodianthrones, ${ }^{40}$ naphtoquinones, ${ }^{41}$ binaphtoquinones,${ }^{42}$ polyunsaturated fatty acids, ${ }^{43}$ derivatives of the chromone nucleus, and many substances isolated from plants. ${ }^{44}$ In medicine, compounds from the anthracycline and epipodophylotoxin classes stand out as potent topoisomerase II inhibitors. These act by inhibiting DNA rebinding, and inducing the binding of proteins at breaks, constituting part of first line chemotherapy for a large variety of solid and hematological tumors. Etoposide, a semisynthetic derivative of the lignan podophyllotoxin, plays an important role in clinical treatments as a chemotherapeutic agent for a variety of tumors, including carcinomas, testicular cancer and lymphomas. ${ }^{45}$

According to Rhee et al..$^{46}$ one of the main structural requirements for Topo II inhibition is the presence of a planar chromophore in aromatic rings. Substances with this kind of chromophore can intercalate with DNA causing blockage or enzymatic reading errors during the replication process. Metabolite $\mathbf{2}$ has called our attention for presenting planar chromophores in aromatic rings, and this structural feature might confer inhibitory activity for the topoisomerase enzyme.

The work with $A$. fistularis led to the isolation of four substances: the dibromotyrosine derivatives 3,5-dibromo-4-[3'dimethylamonium] propoxyphenyl]- $N, N, N$-trimethylethanamonium also known as aplysfistularine (1) and 2-(3,5-dibromo-4-methoxyphenyl)- $N, N, N$ -trimethylethanamonium (2), along with aplysterol (3) and 24, 28-didehydroaplysterol (4). 


\section{RESULTS AND DISCUSSION}

\section{Structural analysis and determination}

All the substances were identified by means of their NMR, mass, and infrared spectroscopic data, as well as by comparison with the literature (Figure 1).

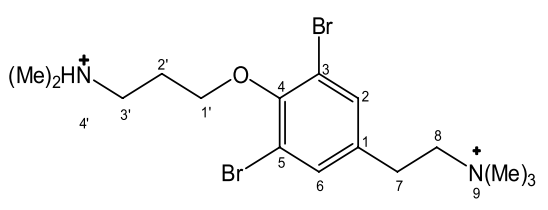

(1)<smiles>COc1c(Br)cc(CCN(C)C)cc1Br</smiles>

(2)<smiles>CC[C@H](C)[C@@H](C)CC[C@H](C)[C@H]1CCC2[C@@]1(C)CCC1[C@@]3(C)CC[C@H](O)CC3=CC[C@]21C</smiles><smiles>C=C(CC[C@@H](C)[C@H]1CCC2[C@@]1(C)CCC1[C@@]3(C)CC[C@H](O)CC3=CC[C@]21C)[C@@H](C)CC</smiles>

Figure 1. Chemical constituents from the sponge Aplysina fistularis

Compound 1 was obtained as an amorphous, yellow solid. Analysis of the molecular formula $\mathrm{C}_{16} \mathrm{H}_{27} \mathrm{ON}_{2} \mathrm{Br}_{2}$ by HRESIMS revealed the fragment $\mathrm{m} / z, 426.0095$ referring to a molecular ion peak. The absorption spectrum in the IR region revealed the presence of absorption bands at 3003-2816, 1300-1100 and at 1591-1412 $\mathrm{cm}^{-1}$, indicative of the presence of saturated $\mathrm{C}-\mathrm{H}$ bonds, aromatic ethers, and aromatic rings $\mathrm{C}=\mathrm{C}$, respectively. ${ }^{47,48}$ The ${ }^{1} \mathrm{H}$ NMR spectrum showed a singlet at $\delta_{\mathrm{H}} 7.32$, suggesting a substituted aromatic system for compound $\mathbf{1}$. The presence of a singlet at $\delta_{\mathrm{H}} 2.32$ integrating to nine hydrogens referring to three $N$-methyl groups, and two multiplets at $\delta_{\mathrm{H}} 2.59$ and 2.71 with integral for two hydrogens each, suggested the presence of an $N, N, N$-trimethylethylammonium group. In the same spectrum, another singlet at $\delta_{\mathrm{H}} 2.49$ corresponding to six hydrogens from two other $N$-methyl groups; two other multiplets of two protons each at $\delta_{\mathrm{H}} 2.15$ and 2.89 , referring to methylene hydrogens; as well as the presence of a triplet with integral to two $\mathrm{H}$ at $\delta_{\mathrm{H}}$ 4.01 , referring to the oxymethylenic $\mathrm{H}$, suggests the existence of an $N, N$-dimethylammonium-propanol group. The NMR spectrum of ${ }^{13} \mathrm{C}$-APT showed eleven spectral signals, four of which $\left(\delta_{\mathrm{C}} 151.30\right.$; $138.58 ; 132.80$ and 118.02 ) were present in the high-frequency region, suggesting a tetra-substituted benzene ring. Signals at $\delta_{\mathrm{C}}$ $132.80 ; 60.20 ; 44.74\left(\mathrm{C}-2 / 6, \mathrm{C}-8\right.$ and $9-\mathrm{N}^{+}(\mathrm{Me})_{3}$, respectively), as well as others at $\delta_{\mathrm{C}} 71.00 ; 26.79 ; 55.77$ and 44.06 (C-1', C-2', C-3' and 4 ' $-\mathrm{NH}^{+}(\mathrm{Me})_{2}$, respectively) corroborated the indication of the ${ }^{1} \mathrm{H}$ NMR spectra for the presence of $N, N, N$-trimethylethylammonium and $N, N$-dimethylammonium-propanol, respectively. In COSY two-dimensional spectrum, we observed a correlation between signals at
$\delta_{\mathrm{H}} 2.71$ and $\delta_{\mathrm{H}} 2.59$, which allowed us to identify methylene hydrogens from positions seven and eight, respectively, and suggest the presence of an $\mathrm{N}, \mathrm{N}, \mathrm{N}$-trimethylethylammonium group. A correlation between signals at $\delta_{\mathrm{H}} 4.01$ and $\delta_{\mathrm{H}} 2.15$, and the signal at $\delta_{\mathrm{H}} 2.89$ also allowed the assignment of oxymethylene hydrogens from positions $\mathrm{H}-1$ ', $\mathrm{H}-2$ ' and $\mathrm{H}-3$ ' and proposal of the presence of $\mathrm{N}, \mathrm{N}, \mathrm{N}$-trimethylethylammonium and $N, N$-dimethylammonium-propanol. The HMBC correlation spectrum confirmed previous assignments, and allowed us to define the position of substitution in the benzene ring. A two-bond correlation between signals at $\delta_{\mathrm{H}} 2.71(\mathrm{H}-7)$ and $\delta_{\mathrm{C}} 138.58(\mathrm{C}-1)$, as well as a three-bond correlation between signals at $\delta_{\mathrm{H}} 7.32(\mathrm{H}-2 / 6)$ and $\delta_{\mathrm{C}} 32.26$ (C-7) allows us to affirm that an $N, N, N$-trimethylethylammonium group is inserted into position 1 of the benzene ring. We also observed a three-bond correlation between signals of $\mathrm{H}-2 / 6\left(\delta_{\mathrm{H}} 7.32\right)$ and of C-4 $\left(\delta_{\mathrm{C}} 151.30\right)$, which permitted us to infer that the oxygenated group $\mathrm{N}, \mathrm{N}$-dimethylammonium-propanol is inserted into position 4 , since C-4 is deshielded compared to other carbons of the benzene ring (Table 1). Spectral data analysis of ${ }^{1} \mathrm{H}$ and ${ }^{13} \mathrm{C}$ NMR of compound $\mathbf{1}$ allowed us to identify it as a dibromotyrosine derivative, whose chemical name is 3,5-dibromo-4-[3'dimethylamonium] propoxyphenyl]- $N, N, N$-trimethylethanamonium, which was denominated "Aplysfistularine" (1).

\section{In vitro assay for inhibitory activity against human DNA topoisomerase II- $\alpha$}

The presence of the planar chromophore, due to the aromatic ring, confers compound $\mathbf{2}$ the possibility of interacting with the Topo II- $\alpha$ enzyme. Due to this structural feature, we evaluated the possible action of $\mathbf{2}$ on the human DNA Topo II- $\alpha$ from DNA plasmid relaxation assays. Compound $\mathbf{1}$ was not tested for Topoisomerase II- $\alpha$ activity due to the paucity of the material for the experiments.

Figure 2 shows the catalytic activity inhibition for the enzyme DNA topoisomerase II- $\alpha$, observed in vitro with plasmid DNA ( $p$ BR322) relaxation in the presence of ATP and $\mathrm{Mg}^{2+}$. Both the steroid mixture (aplysterol/24,28-didehydroaplysterol), and compound 2 exhibited complete Topo II- $\alpha$ inhibition at $100 \mu \mathrm{M}$ concentrations, as can be seen on lanes 5 in Figures 2B and 2C, respectively. In Figure $2 \mathrm{C}$, no Topo II- $\alpha$ inhibition is evident at 25,12 and $1 \mu \mathrm{M}$ concentrations. This result was compared with etoposide, a well-known inhibitor specific to Topo II- $\alpha$, which was used as a control $(100 \mu \mathrm{M})$, and presents a similar profile to that observed for the steroid mixture and compound 2 (Figures $2 \mathrm{~B}$ and $2 \mathrm{C}$ ). The minimum concentration for inhibitory activity was determined as $50 \mu \mathrm{M}$ for the steroid mixture tested (lane 4 of Figure 2B).

Compound $\mathbf{2}$ and the steroid mixture showed inhibitory activity against human DNA-Topo II- $\alpha$, and would be a good prototype for future investigations for new anti-tumor agents.

\section{EXPERIMENTAL}

\section{Instruments}

Infrared (IR) spectra were registered in $\mathrm{KBr}$ pellets, on a Bomem model MB 100 spectrophotometer. Mass spectra were obtained on a Q-TOF-Micromass mass spectrometer with analysis by Electrospray Ionization (+) on a hybrid Quadrupole Time of Flight (QTOF) device. Samples were dissolved and diluted in a methanol: $\mathrm{H}_{2} \mathrm{O}(1: 1)$ solution with formic acid at $0.01 \%$ to the concentration of $1.0 \mu \mathrm{g} \mathrm{mL}^{-1}$. The spectra were obtained in positive ion mode. The injection flow was $1.0 \mathrm{~mL} \mathrm{~min}{ }^{-1}$. One and two-dimensional NMR of ${ }^{1} \mathrm{H}$ and ${ }^{13} \mathrm{C}$ spectra were obtained on a Bruker spectrometer NMR (DRX 500), and Varian System spectrometer NMR (500) operating at $500 \mathrm{MHz}\left({ }^{1} \mathrm{H}\right)$ 


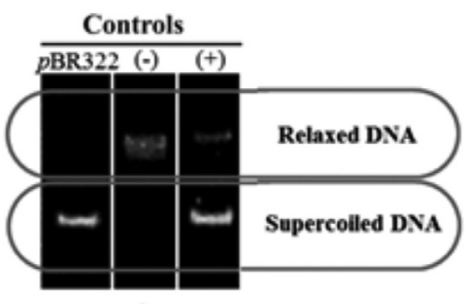

A

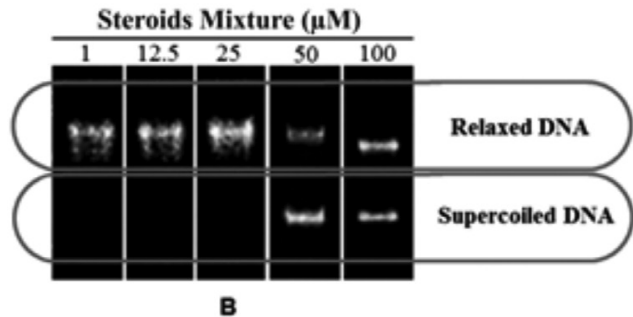

B

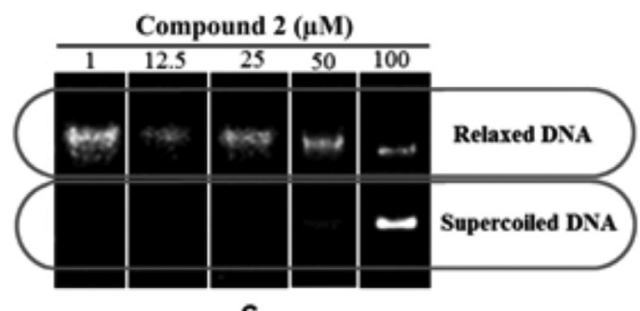

C

Figure 2. Inhibitory activity of Human DNA Topoisomerase II- $\alpha$ by chemical constituents of the marine sponge Aplysina fistularis. (A) $0.125 \mu \mathrm{g} / \mathrm{mL}^{-1}$ of DNA supercoiled plasmid pBR322 electrophoresed in 1\% agarose gel alone (lane 1A); $0.125 \mu \mathrm{g} / \mathrm{mL}^{-1}$ of Human DNA with 1.0 unit of Topo II- $\alpha$ enzyme (lane $2 A$ ), negative control or treated with both $0.125 \mu \mathrm{g} / \mathrm{mL}^{-1}$ of Human DNA, 1.0 unit of Topo II- $\alpha$ enzyme and its inhibitor $100 \mu M$ Etoposide (lane 3A) as positive control. Plasmid incubated with enzyme and several concentrations of steroids mixture (Aplysterol and 24-28-didehydroaplysterol) $(\boldsymbol{B})$ or Compound $2(\boldsymbol{C})$, from A. fistularis. Concentrations from 1 to $100 \mu M$ for each inhibitor candidate. With exception of lane $1 A$, all lanes contain $0.125 \mu \mathrm{g} / \mathrm{mL}^{-1}$ of the plasmid DNA pBR322 and 1.0 unit of TopoII- $\alpha$ enzyme and at $125 \mathrm{MHz}\left({ }^{13} \mathrm{C}\right)$. Deuterated solvents from Cambridge Isotope Laboratories were used (CIL) $\left(\mathrm{CDCl}_{3}, \mathrm{CD}_{3} \mathrm{OD}\right)$.

\section{Collection, processing and fractionation of Aplysina fistularis}

The sponge A. fistularis was collected in the sea canyons of the State of Paraíba, Brazil. The species were registered under numbers 63 and 65, and deposited in the Paulo Yang Marine Invertebrates Collection, at the Department of Systematics and Ecology of the Universidade Federal da Paraíba. As soon as they were collected, the specimens were preserved in ethanol. The crude ethanol extract was equivalent to $16.65 \%$ of the dry weight of the sponges. This extract was subjected to a liquid-liquid partition with hexane, dichloromethane and ethyl acetate. The dichloromethane fraction was subjected to a series of Column chromatography over Sephadex LH-20 (pure methanol as eluent) and also silica gel (gradients of methanol:dichloromethane or methanol:ethyl acetate). The fractions containing the dibromotyrosine derivatives (detected by TLC under UV light $254 \mathrm{~nm}$ ) were purified by column chromatography over silica gel using a gradient of methanol:dichloromethane. The chromatographic fractionation of the ethanol extract of the sponge A. fistularis yielded the newly isolated $\mathbf{1}$, the known substance $\mathbf{2}$ and a mixture of the steroids $\mathbf{3}$ and $\mathbf{4}$, at a 1:1 proportion.

\section{Aplysfistularine (1)}

Amorphous yellow solid: Solubility: chloroform; $\mathrm{C}_{16} \mathrm{H}_{27} \mathrm{ON}_{2} \mathrm{Br}_{2}$ Mol. wt.: 426.00 u.m.a; IR (KBr) $v_{\max } 3426,3003,2976,2938,2862$, 2816, 2335 1300-1100, 1259, 1440-1600 $\mathrm{cm}^{-1} ;{ }^{1} \mathrm{H}$ and ${ }^{13} \mathrm{C}$ NMR data, Table 1; HRESIMS: $\mathrm{m} / \mathrm{z}$ 204.0344; $\mathrm{m} / \mathrm{z} 205.0240$ (molecular ion); $\mathrm{m} / \mathrm{z}$, 206.0330; $\mathrm{m} / \mathrm{z}, 252.0204 ; \mathrm{m} / \mathrm{z}, 423.0365 ; \mathrm{m} / \mathrm{z}, 425.0173 ; \mathrm{m} / \mathrm{z} 426.0095$.

\section{2-(3,5-Dibromo-4-methoxyphenyl)-N,N,N-trimethylethanamonium} (2)

Amorphous yellow solid; Solubility: methanol; $\mathrm{C}_{12} \mathrm{H}_{18} \mathrm{Br}_{2} \mathrm{NO}$ Mol. wt.: 352.08 u.m.a; IR (KBr) $v_{\max } 3426,3003$, 2976, 2938, 2862, 2816, 2335, 1440-1600; 1300-1100, $1259\left(\mathrm{~cm}^{-1}\right) ;{ }^{1} \mathrm{H}$ and ${ }^{13} \mathrm{C}$ NMR data, Table 1; HRESIMS: $m / z$ 349.9877; $m / z, 351.9876$ (molecular

Table 1. NMR data of ${ }^{1} \mathrm{H}(500 \mathrm{MHz})$ and ${ }^{13} \mathrm{C}(125 \mathrm{MHz})$ for compounds $\mathbf{1}$ and $\mathbf{2}(\delta$ in ppm)

\begin{tabular}{|c|c|c|c|c|c|c|c|}
\hline & \multicolumn{4}{|c|}{$\mathbf{1}\left(\right.$ Measured in $\mathrm{CDCl}_{3}$ ) } & \multicolumn{3}{|c|}{2 (Measured in $\left.\mathrm{CD}_{3} \mathrm{OD}\right)$} \\
\hline & \multicolumn{2}{|c|}{ HMQC } & \multicolumn{2}{|c|}{ HMBC } & \multicolumn{2}{|c|}{ HMQC } & \multirow{2}{*}{$\begin{array}{c}\mathrm{HMBC} \\
{ }^{2} J_{\mathrm{CH}} \mathrm{e}^{3} J_{\mathrm{CH}}\end{array}$} \\
\hline & $\delta_{\mathrm{C}}$ & $\delta_{\mathrm{H}}$ & ${ }^{2} J_{\mathrm{CH}}$ & ${ }^{3} J_{\mathrm{CH}}$ & $\delta_{\mathrm{C}}$ & $\delta_{\mathrm{H}}$ & \\
\hline \multicolumn{8}{|l|}{$\mathbf{C}$} \\
\hline 1 & 138.58 & - & $2 \mathrm{H}-7$ & - & 136.32 & - & $\mathrm{H}-2 / \mathrm{H}-6 ; 2 \mathrm{H}-7 ; 2 \mathrm{H}-8$ \\
\hline $3 / 5$ & 118.02 & - & $\mathrm{H}-2 / \mathrm{H}-6$ & - & 119.38 & - & H-2/H-6 \\
\hline 4 & 151.30 & - & - & $\mathrm{H}-2 / \mathrm{H}-6$ & 154.90 & - & H-2/H-6; MeO-4 \\
\hline \multicolumn{8}{|l|}{$\mathbf{C H}$} \\
\hline $2 / 6$ & 132.80 & $7.32, \mathrm{~s}$ & - & $2 \mathrm{H}-7$ & 134.80 & $7.64, \mathrm{~s}$ & $2 \mathrm{H}-7$ \\
\hline \multicolumn{8}{|l|}{$\mathrm{CH}_{2}$} \\
\hline 7 & 32.26 & $2.71, \mathrm{~m}$ & $2 \mathrm{H}-8$ & H-2/H-6 & 28.98 & $3.12, \mathrm{~m}$ & $2 \mathrm{H}-8$ \\
\hline 8 & 60.20 & $2.59, \mathrm{~m}$ & $2 \mathrm{H}-7$ & $\mathrm{Me}_{3} \mathrm{~N}-8$ & 67.80 & $3.58, \mathrm{~m}$ & $\mathrm{Me}_{3} \mathrm{~N}-8$ \\
\hline 1 & 71.00 & $4.01,(t, J=6.0 \mathrm{~Hz})$ & 2H-2' & $2 \mathrm{H}-3$ & - & - & - \\
\hline $2^{\prime}$ & 26.79 & $2.15, \mathrm{~m}$ & $2 \mathrm{H}-1^{\prime} ; 2 \mathrm{H}-3{ }^{\prime}$ & & - & - & - \\
\hline $3^{\prime}$ & 55.77 & $2.89, \mathrm{~m}$ & - & $2 \mathrm{H}-1^{\prime} ; \mathrm{Me}_{2} \mathrm{~N}-3^{\prime}$ & - & - & - \\
\hline \multicolumn{8}{|c|}{$\mathrm{NMe}_{2} / \mathrm{NMe}_{3}$} \\
\hline 9 & 44.74 & $2.32, \mathrm{~s}$ & - & $2 \mathrm{H}-8$ & $\begin{array}{l}53.96 \\
53.93 \\
53.91\end{array}$ & $3.23, \mathrm{~s}$ & - \\
\hline 4 & 44.06 & $2.49, \mathrm{~s}$ & - & $2 \mathrm{H}-1$ & - & - & - \\
\hline \multicolumn{8}{|l|}{ MeO } \\
\hline 4 & - & - & - & - & 61.35 & $3.85, \mathrm{~s}$ & - \\
\hline
\end{tabular}


ion); $m / z$ 378.9383; $m / z, 380.9276$. NMR data agreed with the literature values. ${ }^{12,49}$

Aplysterol IAmorphous white solid; Solubility: chloroform; $\mathrm{C}_{29} \mathrm{H}_{50} \mathrm{O}$; Mol.wt.: 414 u.m.a; NMR data agreed with the literature values. $^{50}$

\section{4,28-Didehydroaplysterol (4)}

Amorphous white solid; Solubility: Chloroform; $\mathrm{C}_{29} \mathrm{H}_{48} \mathrm{O}$; Mol. wt.: 412 u.m.a; NMR data agreed with the literature values. ${ }^{50}$

\section{In vitro assay for topoisomerase II- $\alpha$}

The conversion of $p$ BR322 supercoiled plasmid DNA to the relaxed form by the enzymes topoisomerase II- $\alpha$ was examined. The DNA relaxation assay was analyzed by following the protocol described by topoGEN (topoGEN, Columbus, OH, USA). One unit of topo II- $\alpha$ (human recombinant in E. coli, USB Corporation) enzymes were incubated with $0.125 \mu \mathrm{g} / \mathrm{mL}^{-1}$ of $p$ BR322 DNA (Invitrogen), in the presence of $100 \mu \mathrm{M}$ of compound $\mathbf{2}$, and of the steroid mixture separately, or (in the absence of the test compounds) in $10 \mu \mathrm{L}$ of a mixture containing 10 mM Tris, pH 7.9, $50 \mathrm{mM} \mathrm{NaCl}, 50 \mathrm{mM} \mathrm{KCl}, 5 \mathrm{mM} \mathrm{MgCl}, 0.1 \mathrm{mM}$ EDTA, $15 \mu \mathrm{g}$ mM BSA and $1 \mathrm{mM}$ ATP, $10 \mathrm{mM} \mathrm{Na}_{2} \mathrm{HPO}_{4}$ and $0.2 \mathrm{mM}$ DTT for $40 \mathrm{~min}$ at $37{ }^{\circ} \mathrm{C}$. The reaction was stopped by the addition of $1 \mu \mathrm{L}$ of a solution consisting of $10 \%$ sodium dodecyl sulfate (SDS) and $25 \%$ bromophenol blue and $50 \%$ glycerol. Etoposide was used as the positive control. Electrophoresis was carried out over $1 \%$ agarose gel plates, in TAE buffer, at $\mathrm{pH} 8.5$, for $120 \mathrm{~min}$ at $40 \mathrm{~V}$.

\section{CONCLUSION}

The chemical study of A. fistularis led to the isolation of a new dibromotyrosine derivative: Aplysfistularine, and its first description in the literature. Since the isolated compounds in this paper are considered to be chemotaxonomic markers of the species, we believe it to be an important contribution to the study of the species.

The substances isolated from A. fistularis inhibited the action of human DNA topoisomerase II- $\alpha$ at concentrations of 50 and 100 $\mu \mathrm{M}$. Further biological evaluations are in progress to determine the compound's potency. Due to their great diversity, marine sponges represent a promising source of secondary metabolites. This study shows their importance for natural product chemistry and pharmacology by presenting compounds isolated from A. fistularis with inhibitory activity on the human topoisomerase II- $\alpha$ DNA enzyme.

\section{SUPPLEMENTARY MATERIAL}

${ }^{1} \mathrm{H}$ and ${ }^{13} \mathrm{C}$ NMR spectra, COSY, HMQC, HMBC, NOESY spectra, and HRESIMS spectra of compounds $\mathbf{1}$ and $\mathbf{2}$ as well as the HSQC-TOCSY spectra of compound $\mathbf{1}$ are available at http:// quimicanova.sbq.org.br, in PDF file, with free access.

\section{ACKNOWLEDGEMENTS}

This work was financially supported by CNPq/FAPESQ/ PRONEX/INCTAmtTropic-Brazil. We are also extremely grateful to NUCAL/LTF and CENAUREM/UFC for conducting the spectra of $500 \mathrm{MHz}$. The authors are also grateful to the technicians V. C. de O. Costa, Raimundo N. da Silva Filho and D. E. de A. Uchoa for the technical support.

\section{REFERENCES}

1. Costa-Lotufo, L. V.; Wilke, D. V.; Jimenez, P. C.; Epifanio, R. A.; Quim.
Nova 2009, 32, 703.

2. Kossuga, M. H.; Lira, S. P.; McHugh, S.; Yohandra, R.; Torres, Y. R.; Lima, B. A.; Gonçalves, R.; Veloso, K.; Ferreira, A. G.; Rocha, R. M.; Berlinck, R. G. S.; J. Braz. Chem. Soc. 2009, 20, 704.

3. Almeida, C. L. F.; Falcão, H. S.; Lima, G. R. M.; Montenegro, C. A.; Lira, N. S.; Athayde-Filho, P. F.; Rodrigues, L. C.; Souza, M. F. V.; Barbosa-Filho, J. M.; Batista, L. M.; Int. J. Mol. Sci. 2011, 12, 4550.

4. Souza, E. T.; Lira, D. P.; Queiroz, A. C.; Silva, D. J. C.; Aquino, A. B.; Mella, E. A. C.; Lorenzo, V. P.; Miranda, G. E. C.; Araújo-Júnior, J. X.; Chaves, M. C. O.; Barbosa-Filho, J. M.; Athayde-Filho, P. F.; Santos, B. V. O.; Alexandre-Moreira, M. S.; Mar. Drugs 2009, 7, 689.

5. Garcia, D. G.; Bianco, E. M.; Santos, M. C. B.; Pereira, R. C.; Faria, M. V. C. F.; Teixeira, V. L.; Burth, P.; Phytother. Res. 2009, 23, 943

6. Silva, C. T. C.; Hernández, L. C.; Reyes, O. E. O.; Rodríguez, F. A. R.; Beltrán, C. D.; Hegedus, M. P.; Quim. Nova 2010, 33, 656.

7. Paula, J. C.; Vallim, M. A.; Teixeira, V. L.; Rev. Bras. Farmacogn. 2011, 21, 216.

8. Matta, C. B. B.; Souza, E. T.; Queiroz, A. C.; Lira, D. P.; Araújo, M. V.; Cavalcante-Silva, L. H. A.; Miranda, G. E. C.; Araújo-Júnior, J. X.; Barbosa-Filho, J. M.; Santos, B. V. O.; Alexandre-Moreira, M.S.; Mar. Drugs 2011, 9, 307.

9. Bitencourt, M. A. O.; Dantas, G. R.; Lira, D. P.; Barbosa-Filho, J. M.; Miranda, G. E. C.; Santos, B. V. O.; Souto, J. T.; Mar. Drugs 2011, 9, 1332.

10. Queiroz, T. M.; Machado, N. T.; Furtado, F. F.; Oliveira-Filho, A. A.; Alustau, M. C.; Figueiredo, C. S.; Miranda, G. E. C.; Barbosa-Filho, J. M.; Braga, V. A.; Medeiros, I. A.; Mar. Drugs 2011, 9, 2075.

11. Almeida, A. M. P.; Berlinck, R. G. S.; Hajdu, E.; Quim. Nova 1997, 20, 170.

12. Granato, A. C.; Berlinck, R. G. S.; Magalhães, A.; Schefer, A. B.; Ferreira, A. G.; Sanctis, B.; Freitas, J. C.; Hajdu, E.; Migotto, A. E.; Quim. Nova 2000, 23, 594.

13. Epifanio, R. A.; Pinheiro, L. S.; Alves, N. C.; J. Braz. Chem. Soc. 2005 , 16, 1367.

14. Lira, S. P.; Seleghim, M. H. R.; Williams, D. E.; Marion, F.; Hamill, P.; Jean, F.; Andersen, R. J.; Hajdu, E.; Berlinck, R. G. S. J.; Braz. Chem. Soc. 2007, 18, 440 .

15. Regalado, E. L.; Laguna, A.; Mendiola, J.; Thomas, O. P.; Nogueiras, C.; Quim. Nova 2011, 34, 289.

16. Kochanowska, A. J.; Rao, K. V.; Childress, S.; El-Alfy, A.; Matsumoto, R. R.; Kelly, M.; Stewart, G. S.; Sufka, K. J.; Hamann, M. T.; J. Nat. Prod. 2008, 71, 186.

17. Ciminiello, P.; Fattorusso, E.; Magno, S.; Magno, A.; J. Nat. Prod. 1994, 57,1564

18. Ciminiello, P.; Dell'Aversano, C.; Fattorusso, E.; Magno, S.; Pansini, M.; J. Nat. Prod. 2000, 63, 263.

19. Granato, A. C.; Oliveira, J. H. L.; Seleghim, M. H. R.; Berlinck, R. G. S.; Macedo, M.; Ferreira, A. G.; Rocha, R. M.; Hajdu, E.; Peixinho, S.; Pessoa, C. O.; Moraes M. O.; Cavalcanti, B. C.; Quim. Nova 2005, 28, 192.

20. Lira, T. O.; Berlinck, R. G. S.; Nascimento, G. G. F.; Hajdu, E.; J. Braz. Chem. Soc. 2006, 17, 1233.

21. Ciminiello, P.; Constantino, V.; Fattorusso, E.; Magno, S.; Mangoni, A.; J. Nat. Prod. 1994, 57, 705.

22. Thoms, C.; Ebel, R.; Proksch, P.; J. Chem. Ecol. 2005, 32, 97.

23. Gandolfi, R. C.; Medina, M. B.; Berlinck, R. G. S.; Lira, S. P.; Galetti, F. C. S.; Silva, C. L.; Veloso, K.; Ferreira, A. G.; Hajdu, E.; Peixinho, S.; Quim. Nova 2010, 33, 1853.

24. Saeki, B. M.; Granato, A. C.; Berlink, R. G. S.; Magalhães, A.; Schefer, A. B.; Ferreira, A. G.; Pinheiro, U. S.; Hajdu, E.; J. Nat. Prod. 2002, 65, 796.

25. Constantinou, A.; Mehta, R.; Runyan, C.; Rao, K.; Vaughan, A.; Moon, R.; J. Nat. Prod. 1995, 58, 217. 
26. Shi, Q.; Chen, K.; Li, L.; Chang, J.; Autry, C.; Kozuka, M.; Konoshima, T.; Estes, J. R.; Lin, C. M.; Hamel, E.; McPhail, D. R.; Lee, K.; J. Nat Prod. 1995, 58, 475.

27. Olano, C.; Méndez, C.; Salas, J. A.; Mar. Drugs 2009, 7, 210.

28. Chan, A. L.-F.; Chang, W.-S.; Chen, L.-M.; Lee, C.-M.; Chen, C.-E.; Lin, C.-M.; Hwang, J.-L.; Molecules 2009, 14, 1342.

29. Grynberg, N. F.; Carvalho, M. G.; Velandia, J. R.; Oliveira, M. C.; Moreira, I. C.; Braz-Filho, R.; Echevarria, A.; Braz. J. Med. Biol. Res. 2002, 35,819 .

30. Maciel, M. A. M.; Martins, J. R.; Pinto, A. C.; Kaiser, C. R.; EstevesSouza, A.; Echevarria, A.; J. Braz. Chem. Soc. 2007, 18, 391.

31. Zhou, N.; Yan, Y.; Li, W.; Wang, Y.; Zheng, L.; Han, S.; Yan, Y.; Li, Y.; Int. J. Mol. Sci. 2009, 10, 3255.

32. Bahia, M. V.; Santos, J. B.; David, J. P.; David, J. M.; J. Braz. Chem Soc. 2005, 16, 1402.

33. Meragelman, T. L.; Silva, G. L.; Mangelli, E.; Gil, R. R.; Phytochemistry 2003, 62, 569 .

34. Wada, S.; Tanaka, R.; Lida, A.; Matsunaga, S.; Bioorg. Med. Chem. Lett. 1998, 8, 2829.

35. Branco, A.; Pinto, A. C; Braz-Filho, R.; Silva, E. F.; Grynberg, N. F.; Echevarria, A.; Rev. Bras. Farmacogn. 2008, 18, 703.

36. Kim, S. I.; Lee, S. H.; Lee, E. S.; Lee, C. S.; Jahng, Y.; Arch. Pharm. Res. 2012, 35, 785.

37. Baunbæk, D.; Trinkler, N.; Ferandin, Y.; Lozach, O.; Ploypradith, P.; Rucirawat, S.; Ishibashi, F.; Iwao, M.; Meijer, L.; Mar. Drugs 2008, 6, 514.

38. Deslandes, S.; Chassaing, S.; Delfourne, E.; Mar. Drugs 2009, 7, 754.

39. Marshall, K. M.; Andjelic, C. D.; Tasdemir, D.; Concepción, G. P.; Ireland, C. M.; Barrows, L. R.; Mar. Drugs 2009, 7, 196.
40. Peebles, K. A.; Baker, R. K.; Kurz, E. U.; Schneider, B. J.; Kroll, D. J.; Biochem. Pharmacol. 2001, 62, 1059.

41. Esteves-Souza, A.; Figueiredo, D. V.; Esteves, A.; Câmara, C. A.; Vargas, M. D.; Pinto, A. C.; Echevarria, A.; Braz. J. Med. Biol. Res. 2007, 40, 1399.

42. Ting, C.; Hsu, C.; Hsu, H.; Su, J.; Chen, T.; Tarn, W.; Kuo, Y.; WhangPeng, J.; Liu, L. F.; Hwang, J.; Biochem. Pharmacol. 2003, 66, 1981.

43. Yonezawa, Y.; Yoshida, H.; Mizushina, Y.; Int. J. Mol. Sci. 2007, 8, 1206.

44. Ishar, M. P. S.; Singh, G.; Singh, S.; Sreenivasan, K. K.; Singh, G.; Bioorg. Med. Chem. Lett. 2006, 16, 1366.

45. De Vita Jr., V. T.; Hellman, S.; Rosenberg, S. A.; Cancer-Principles of Practice of Oncology, $5^{\text {th }}$ ed., Lippincott-Raven: Philadelphia, 1997.

46. Rhee, H.; Park, H. J.; Lee, S. K.; Lee, C.; Choo, H. P.; Bioorg. Med. Chem. 2007, 15, 1651.

47. Silverstein, R. M.; Bassler, G. P. C.; Morril, T. C.; Identificação Espectrométrica de Compostos Orgânicos, $7^{\mathrm{a}}$ ed., Guanabara Koogan: Rio de Janeiro, 2007.

48. Pavia, D. L.; Lampman, G. M.; Kriz, G. S.; Introduction to Spectroscopy, $2^{\text {nd }}$ ed., Saunders College Publishing: Washington, 2001.

49. Kossuga, M. H.; Lira, S. P.; Nascimento, A. M.; Gambardella, M. T. P.; Berlinck, R. G. S.; Torres; Y. H.; Nascimento, G. G. F.; Pimenta, E. F.; Silva, M.; Thiemann, O. H.; Oliva, G.; Tempore, A. G.; Melhem, M. S. C.; Souza, A. O.; Galetti, F. C. S.; Silva, C. L.; Cavalcanti, B.; Pessoa, C. O.; Moraes, M. O.; Hadju, E.; Peixinho, S.; Rocha, R. M.; Quim. Nova 2007, 30, 1194.

50. Kelecom, A.; Kannengiesser, G. J.; Baker, P. M.; An. Acad. Bras. Cienc. 1979, 51, 643 
Narlize Silva Lira, Rubens L. Monte-Neto, João Guilherme B. Marchi, Antônio Cláudio da Silva Lins, Josean Fechine Tavares, Marcelo Sobral da Silva, Celidarque da Silva Dias e José Maria Barbosa-Filho*

Departamento de Ciências Farmacêuticas, Universidade Federal da Paraíba, 58051-900 João Pessoa - PB, Brasil

Creusioni Figueredo dos Santos

Departamento de Biologia Molecular, Universidade Federal da Paraíba, 58051-900 João Pessoa - PB, Brasil

Emídio Vasconcelos Leitão da Cunha

Departamento de Farmácia, Universidade Estadual da Paraíba, 58100-000 Campina Grande - PB, Brasil

Ulisses dos Santos Pinheiro

Departamento de Zoologia, Universidade Federal de Pernambuco, 50373-970 Recife - PE, Brasil

Raimundo Braz-Filho

Centro de Ciências e Tecnologia, Universidade Estadual do Norte Fluminense, 28013-600 Campos dos Gaytacazes - RJ, Brasil

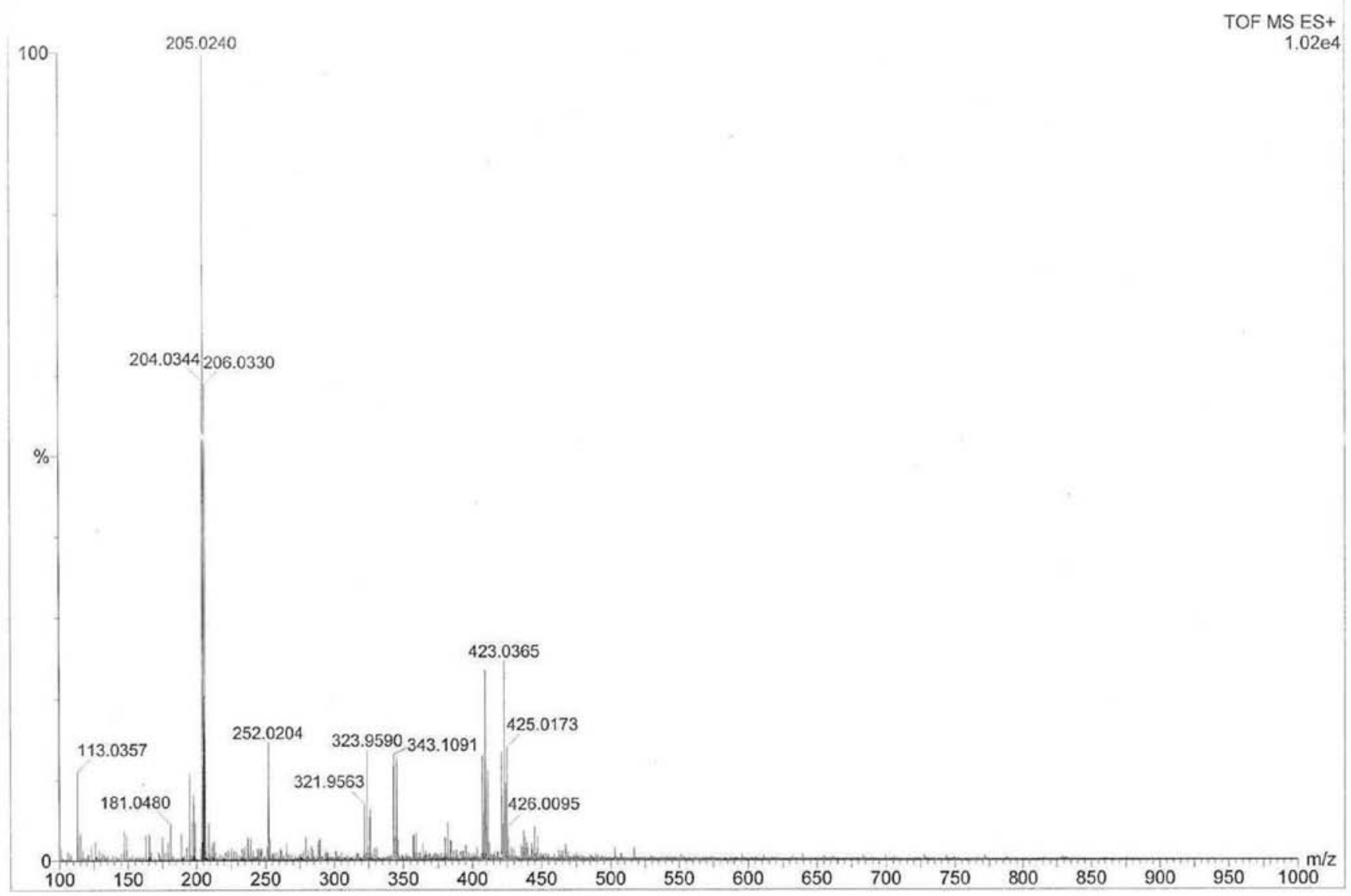

Figure 1S. HRESIMS spectrum of compound 1 


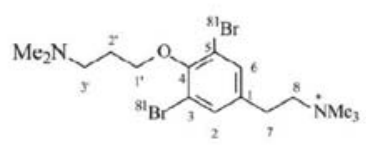

$\mathrm{C}_{16} \mathrm{H}_{27} \mathrm{Br}\left[{ }_{81}\right]_{2} \mathrm{~N}_{2} \mathrm{O}$

$m \mid z 425.0173$

1 (calc $m \mid z 425.0449$ )

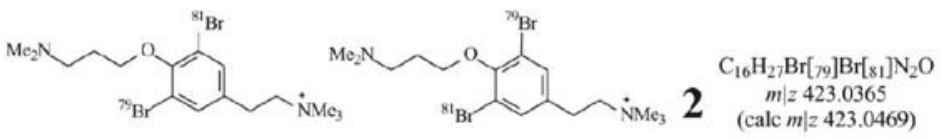

The approximate Relative intensities

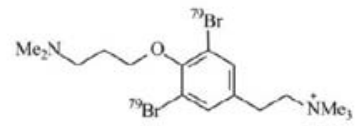

$\mathrm{C}_{16} \mathrm{H}_{27} \mathrm{Br}\left[7_{7}\right]_{2} \mathrm{~N}_{2} \mathrm{O}$

of the ions (with a difference of two

mass units), containing two bromine atoms (isotopes 79 and 81), are

marked in bold.

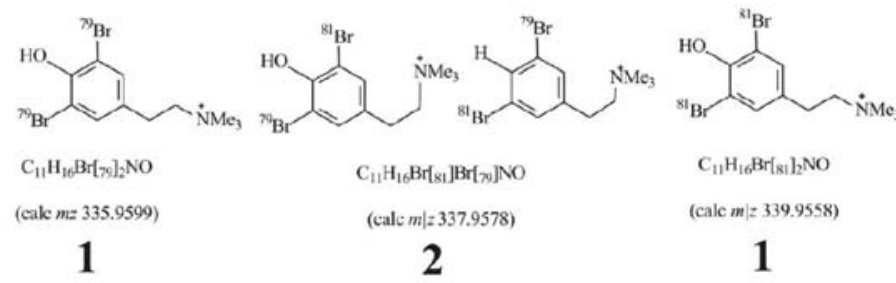

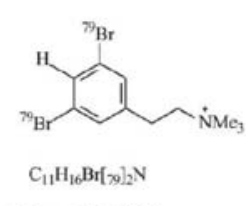

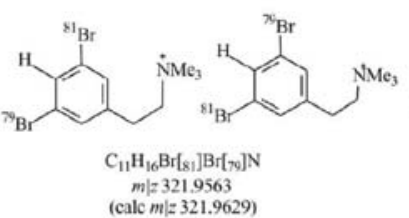

(calc $m \mid z 319.9649$ )

1

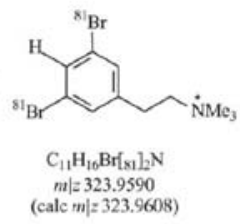

1

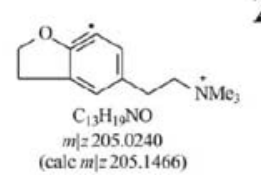

Figure 2S. NMR proposed fragmentation for the molecule of compound $\mathbf{1}$

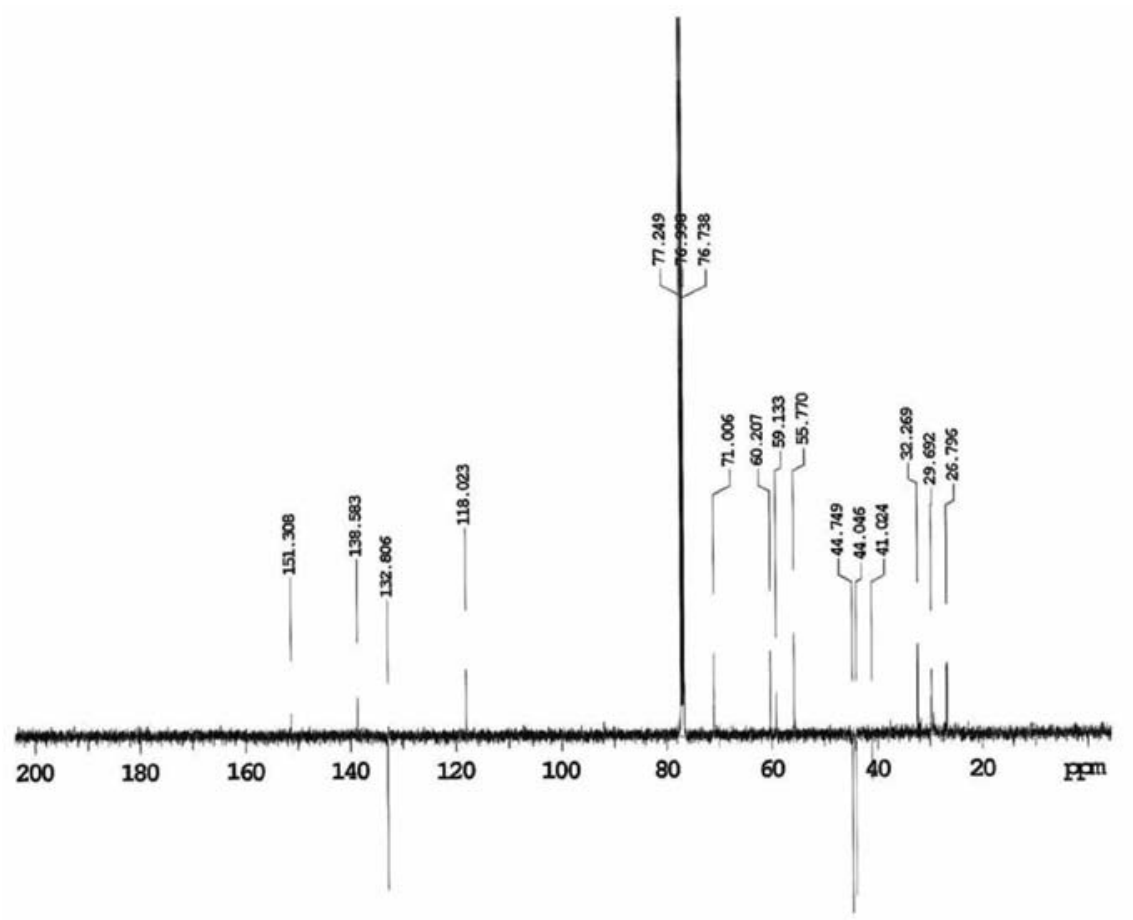




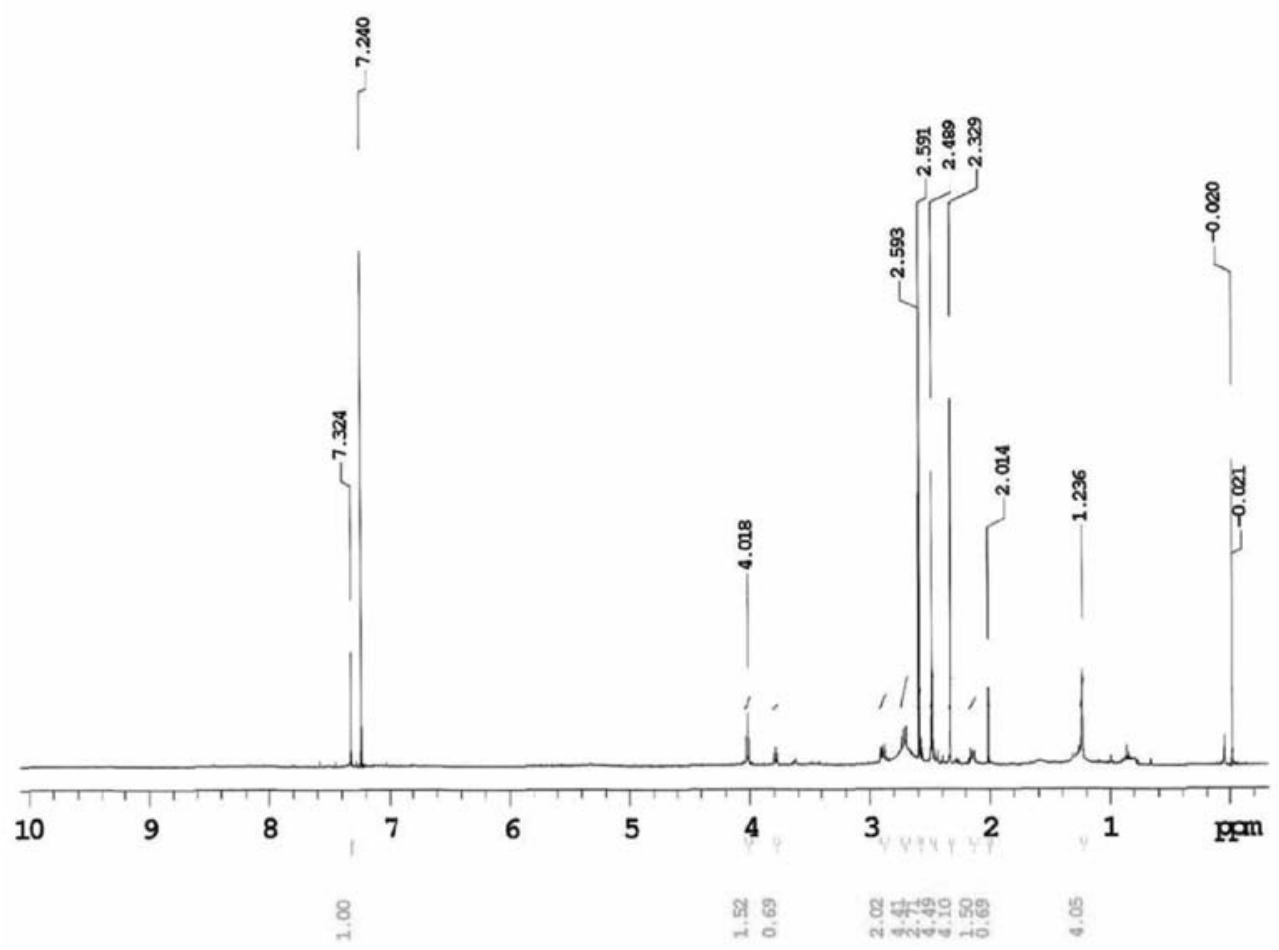

Figure 4S. ${ }^{1} \mathrm{H} N \mathrm{NR}$ spectrum data of compound $1\left(\mathrm{CD}_{3} \mathrm{OD}, 500 \mathrm{MHz}\right)$

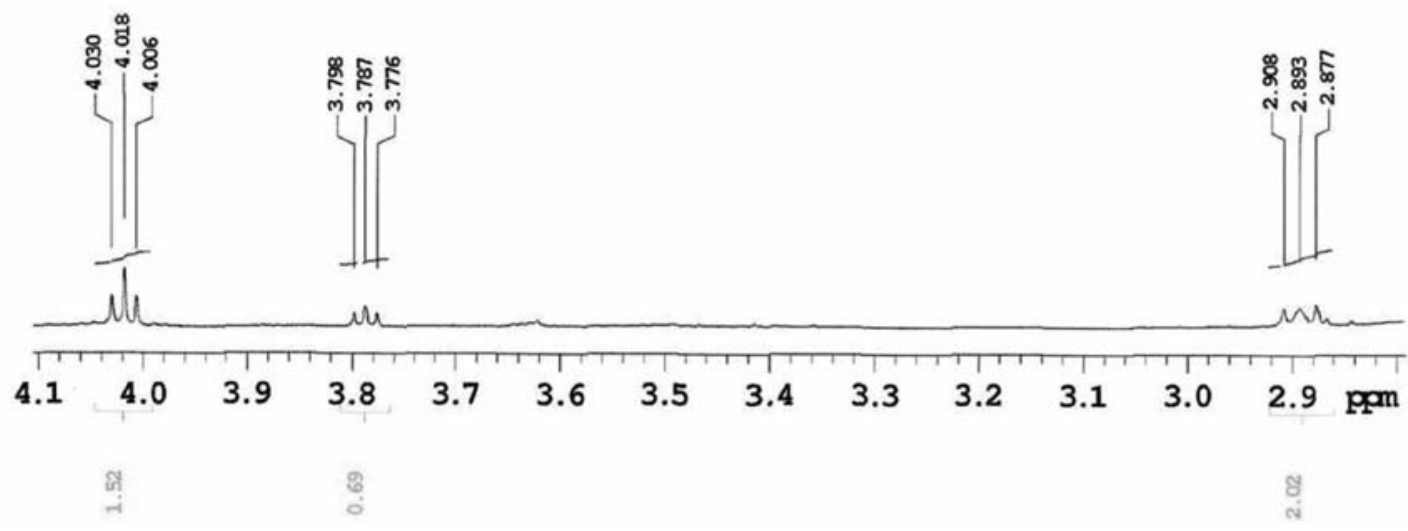

Figure 5S. Expansion of ${ }^{l} \mathrm{H} N M R$ spectrum at the region of $4.1-2.9$ of compound $1\left(\mathrm{CD}_{3} \mathrm{OD}, 500 \mathrm{MHz}\right)$ 


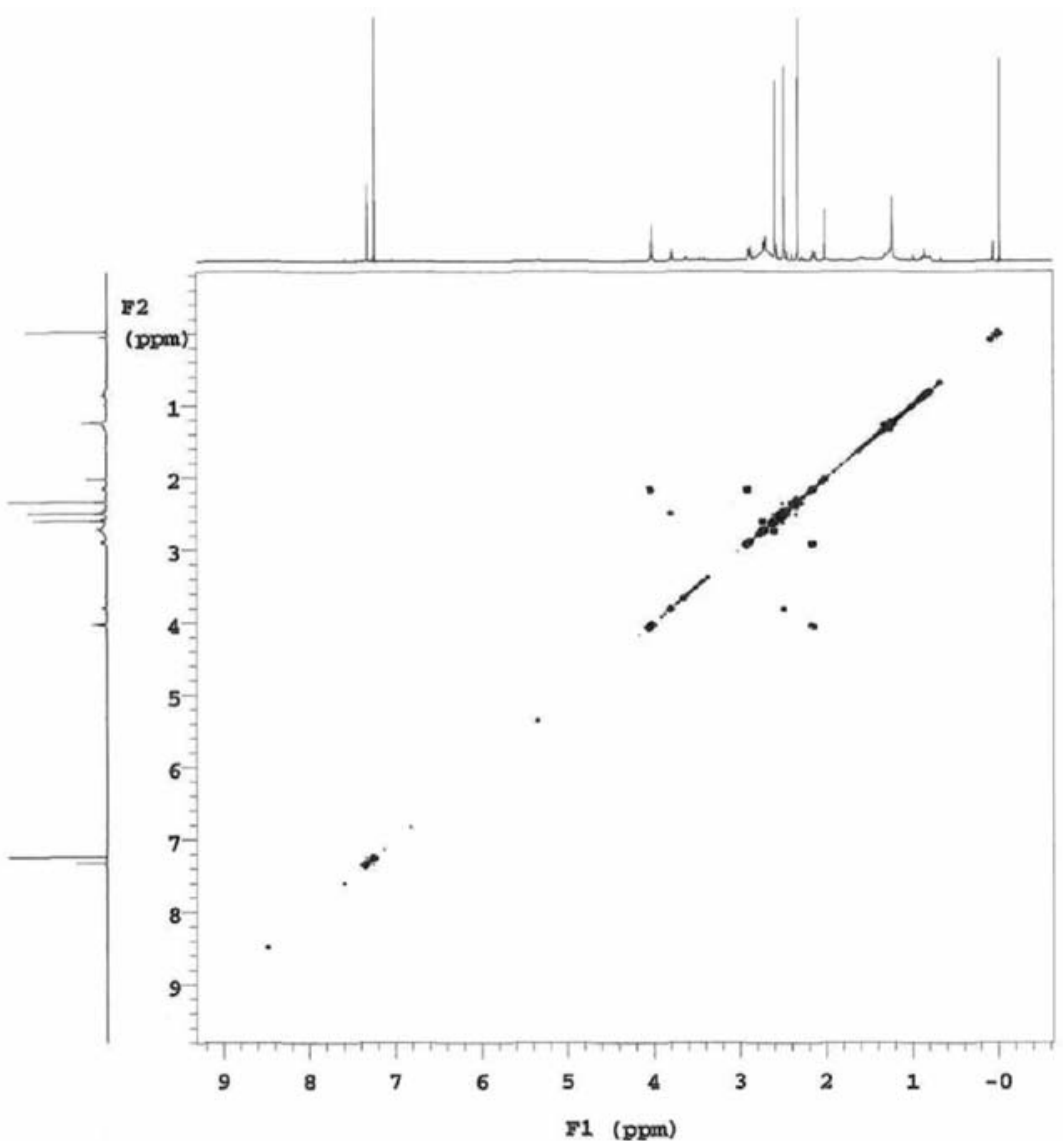

Figure 6S. ${ }^{l} \mathrm{H} x{ }^{l} \mathrm{H}$-COSY correlation spectrum of compound $1\left(\mathrm{CD}_{3} \mathrm{OD}, 500 \mathrm{MHz}\right)$

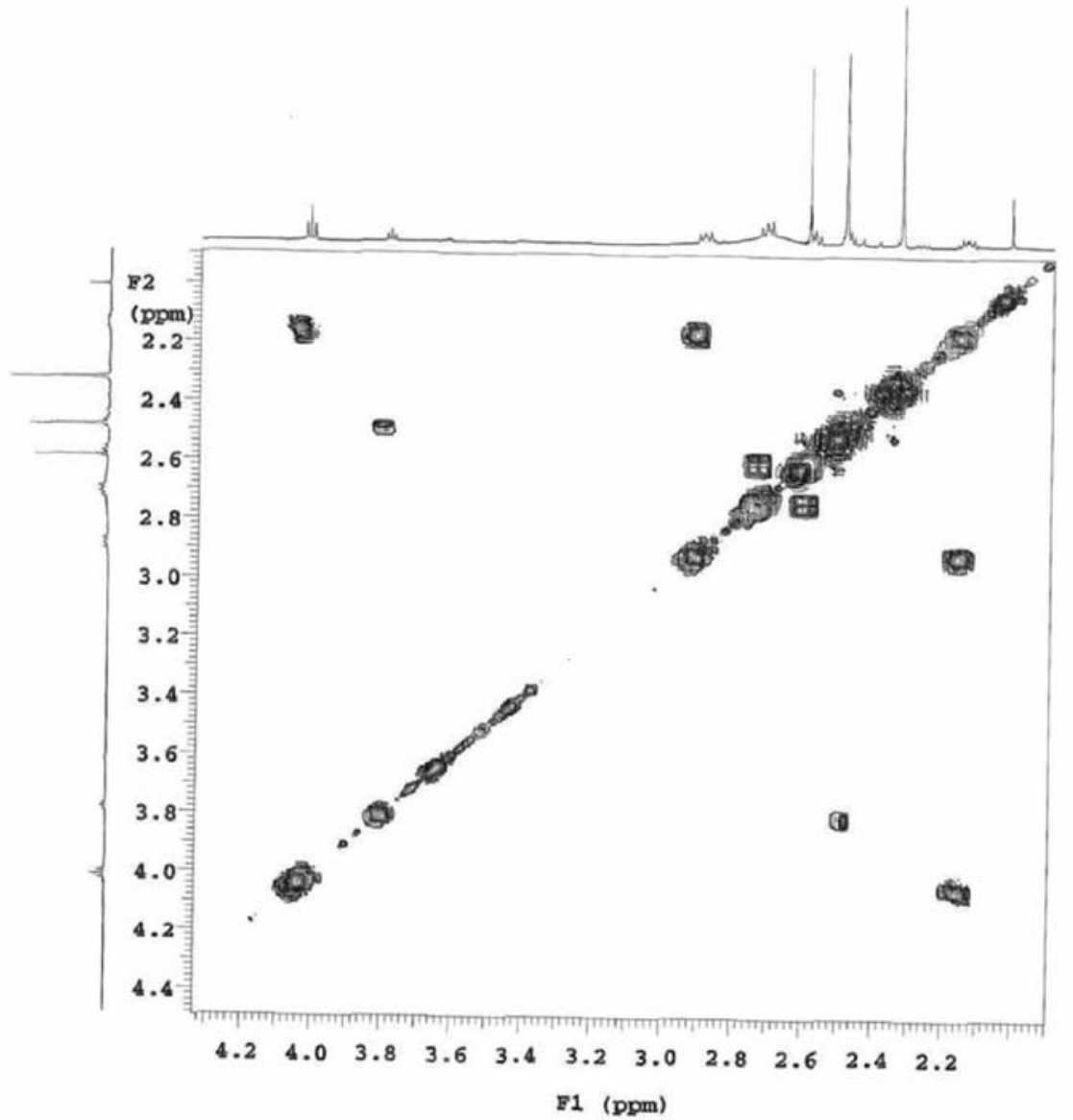

Figure 7S. Expansion of ${ }^{l} \mathrm{H} x^{l} \mathrm{H}$-COSY correlation spectrum of compound $1\left(\mathrm{CD}_{3} \mathrm{OD}, 500 \mathrm{MHz}\right)$ 


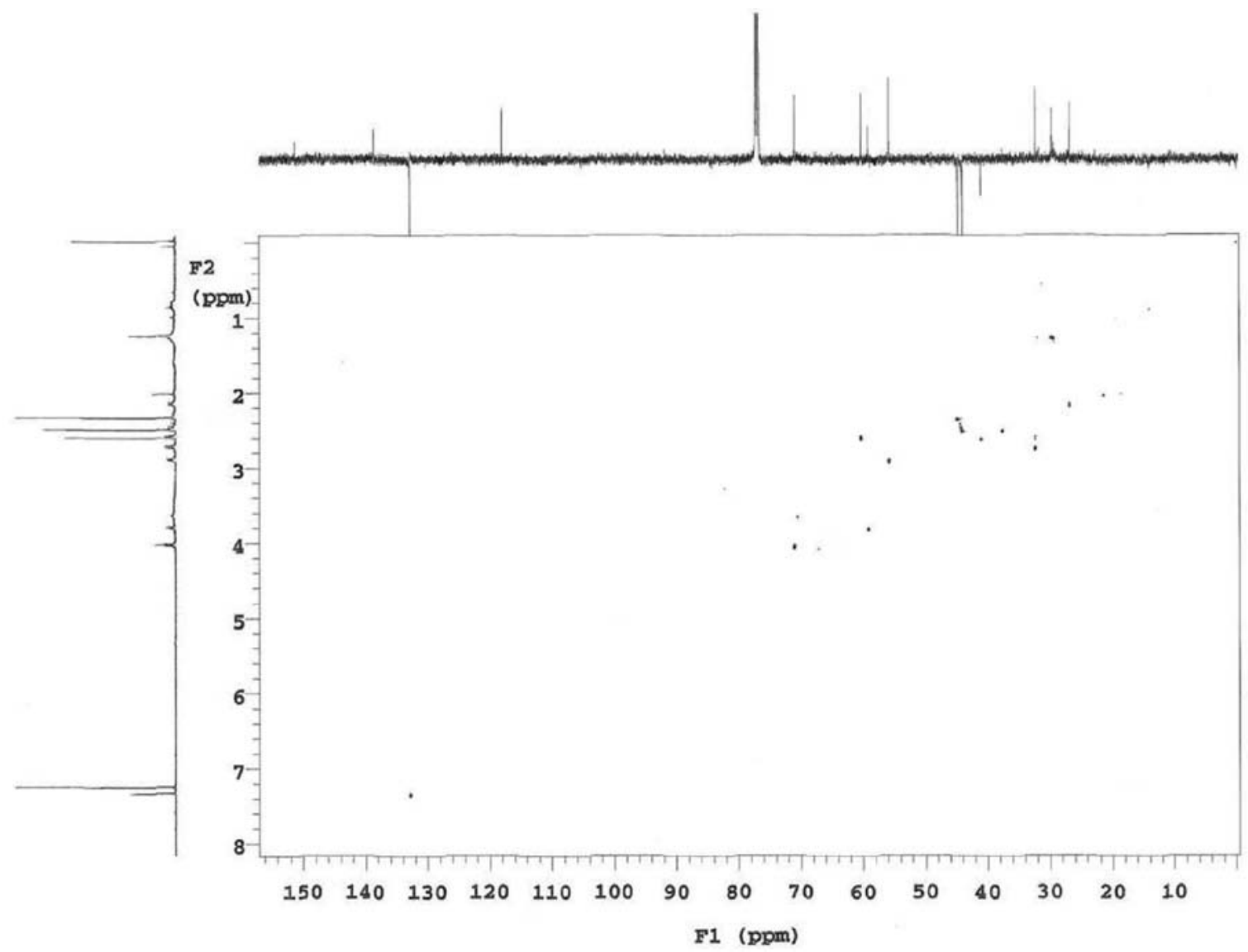

Figure 8S. ${ }^{1} \mathrm{H} x{ }^{13} \mathrm{C}-\mathrm{HMQC}$ correlation spectrum of compound $1\left(\mathrm{CD}_{3} \mathrm{OD}, 500\right.$ and $125 \mathrm{MHz}$ respectively)

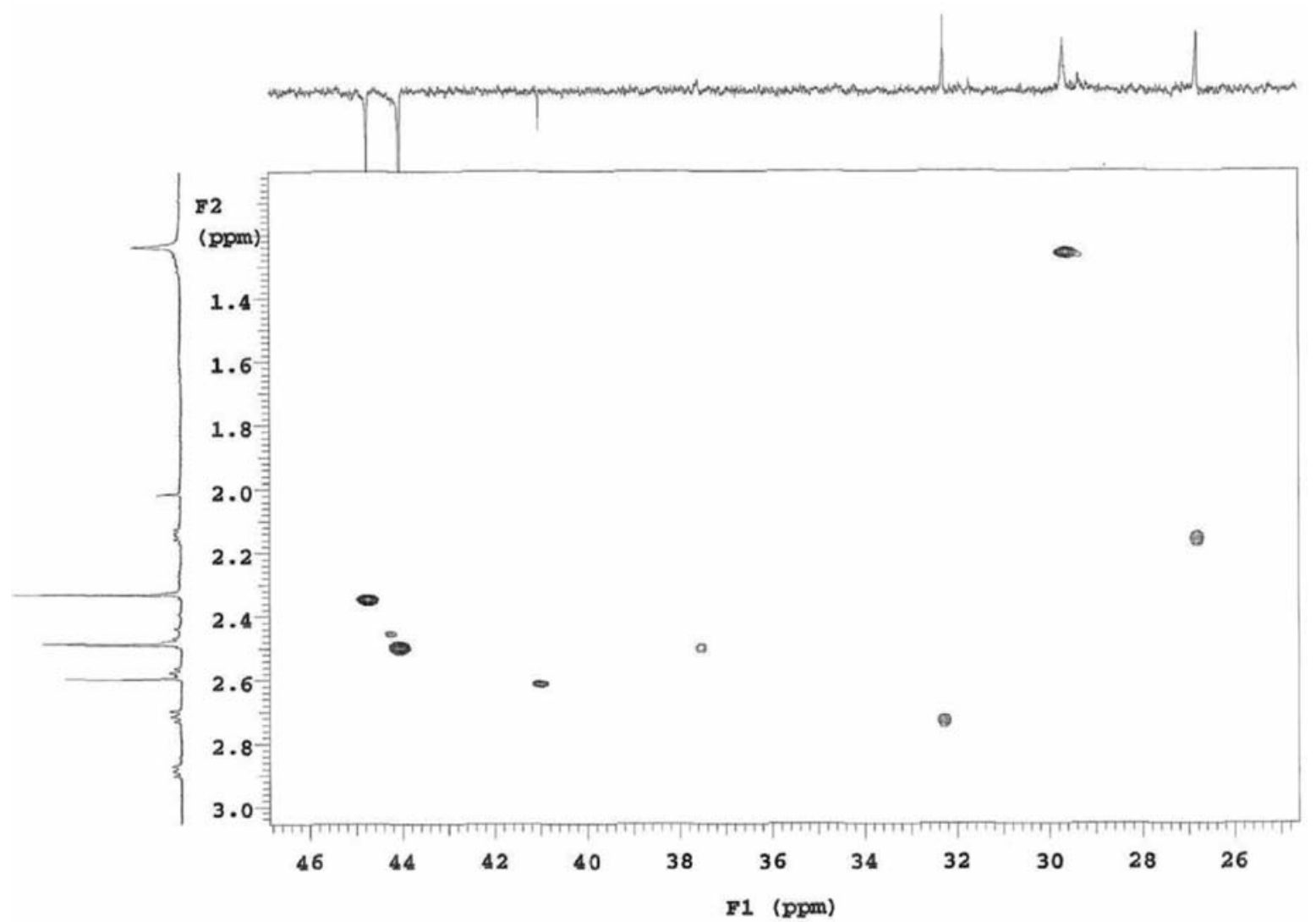

Figure 9S. Expansion of ${ }^{1} \mathrm{H} x{ }^{13} \mathrm{C}$-HMQC correlation spectrum of compound $1\left(\mathrm{CD}_{3} \mathrm{OD}, 500\right.$ and $125 \mathrm{MHz}$ respectively) 


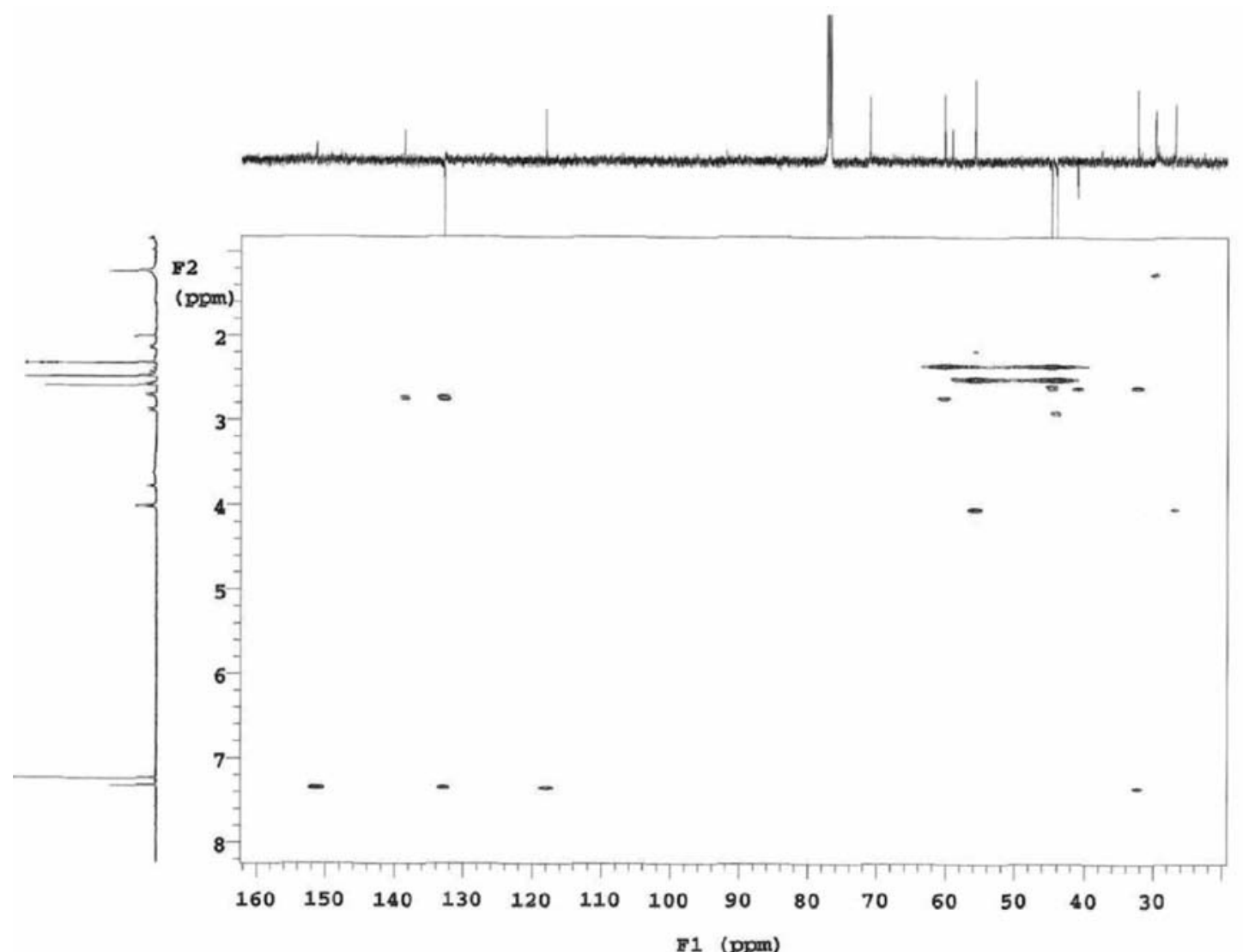

Figure 10S. ${ }^{1} \mathrm{H} x{ }^{13} \mathrm{C}$-HMBC correlation spectrum of compound $1\left(\mathrm{CD}_{3} \mathrm{OD}\right.$, 500 and $125 \mathrm{MHz}$ respectively)

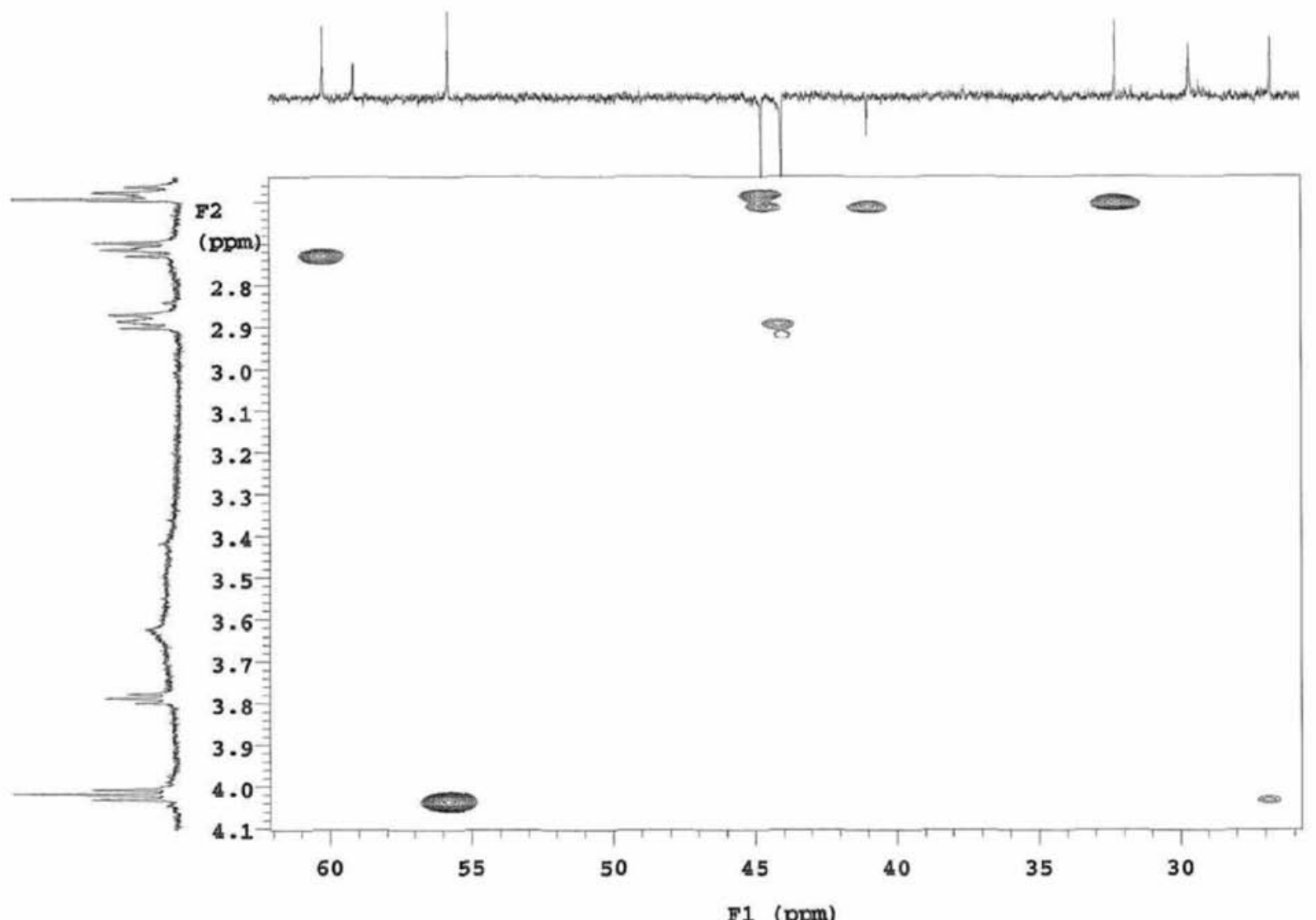

Figure 11S. Expansion of ${ }^{1} \mathrm{Hx}^{13} \mathrm{C}$ - $\mathrm{HMBC}$ correlation spectrum of compound $1\left(\mathrm{CD}_{3} \mathrm{OD}, 500\right.$ and $125 \mathrm{MHz}$ respectively) 


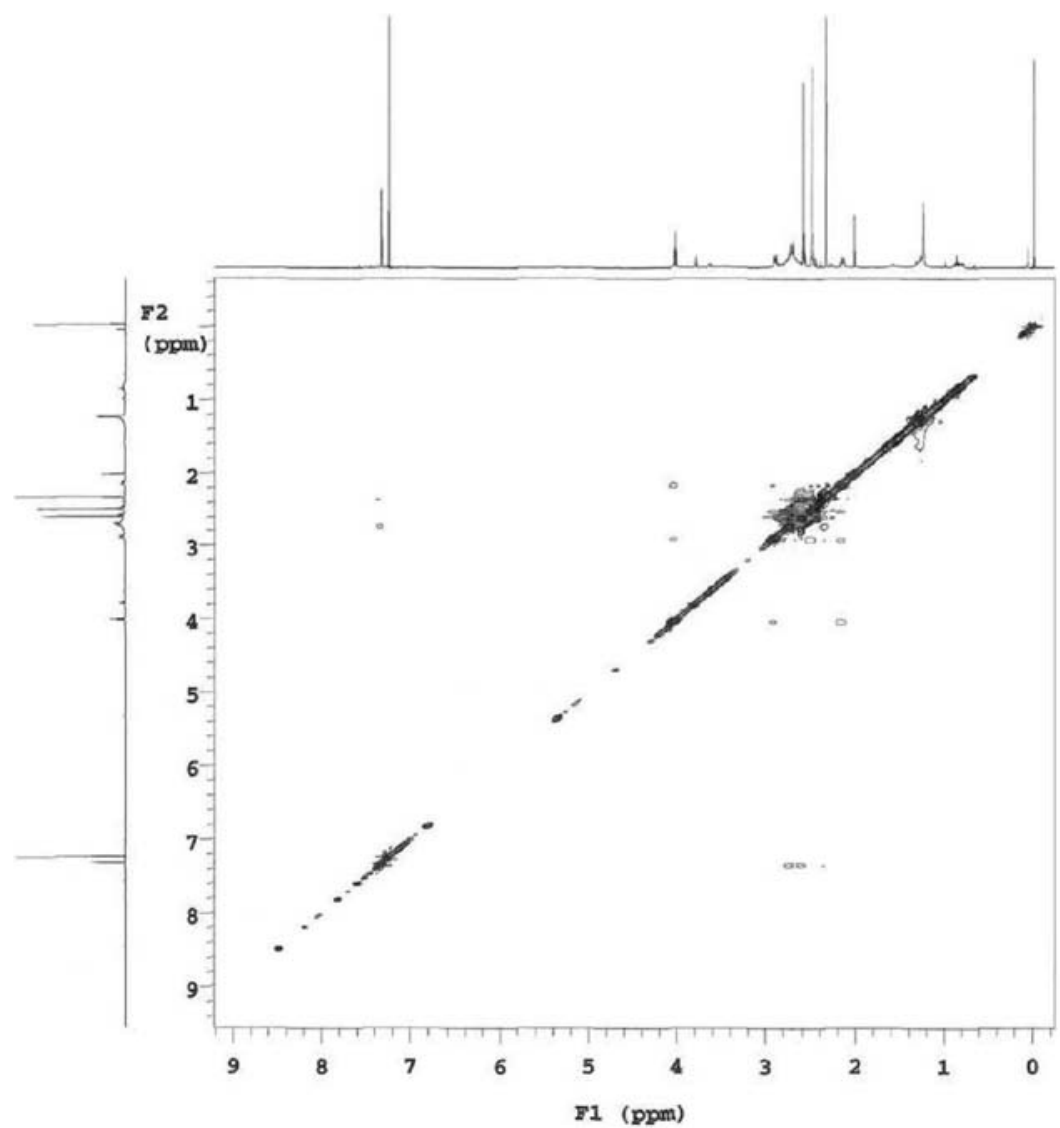

Figure 12S. ${ }^{1} \mathrm{H} x{ }^{1} \mathrm{H}$-NOESY spatial correlation spectrum of compound $1\left(C \mathrm{D}_{3} \mathrm{OD}, 500 \mathrm{MHz}\right)$

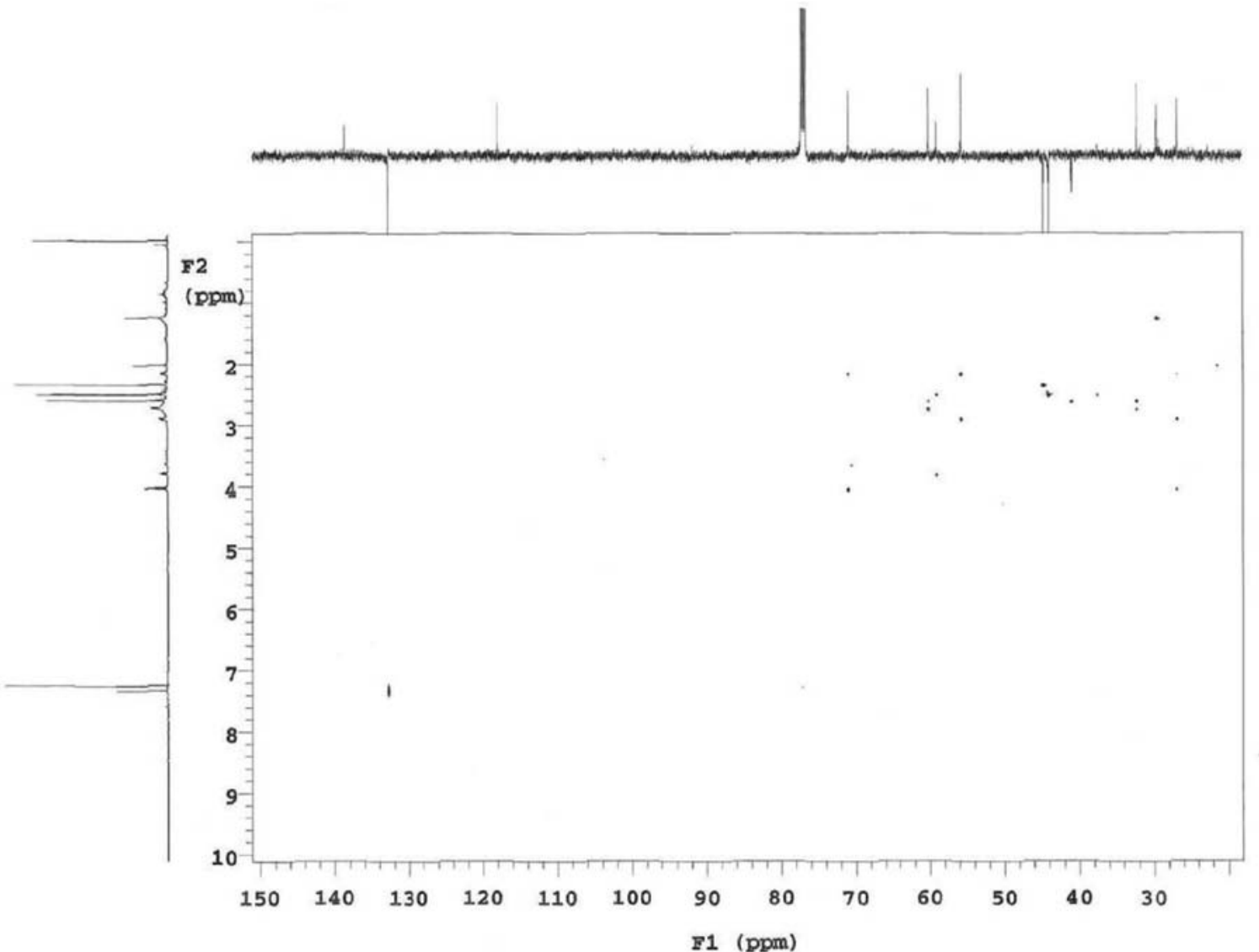

Figure 13S. ${ }^{1} \mathrm{H} x{ }^{13} \mathrm{C}$-HSQC-TOCSY spatial correlation spectrum of compound $1\left(\mathrm{CD}_{3} \mathrm{OD}, 500\right.$ and $125 \mathrm{MHz}$ respectively) 


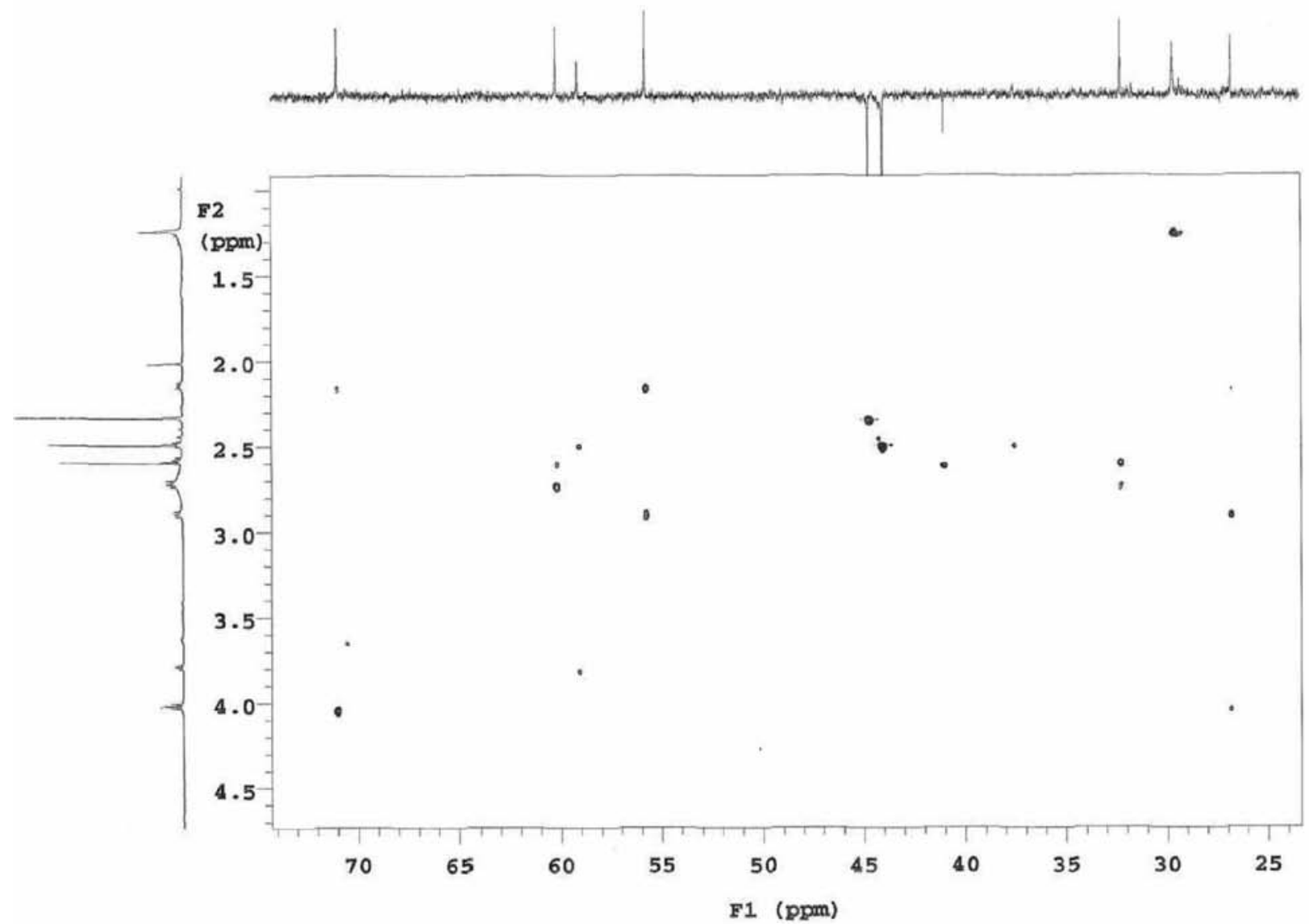

Figure 14S. Expansion of ${ }^{1} \mathrm{H} x{ }^{13} \mathrm{C}$-HSQC-TOCSY spatial correlation spectrum of compound $1\left(\mathrm{CD}_{3} \mathrm{OD}, 500\right.$ and $125 \mathrm{MHz}$ respectively)

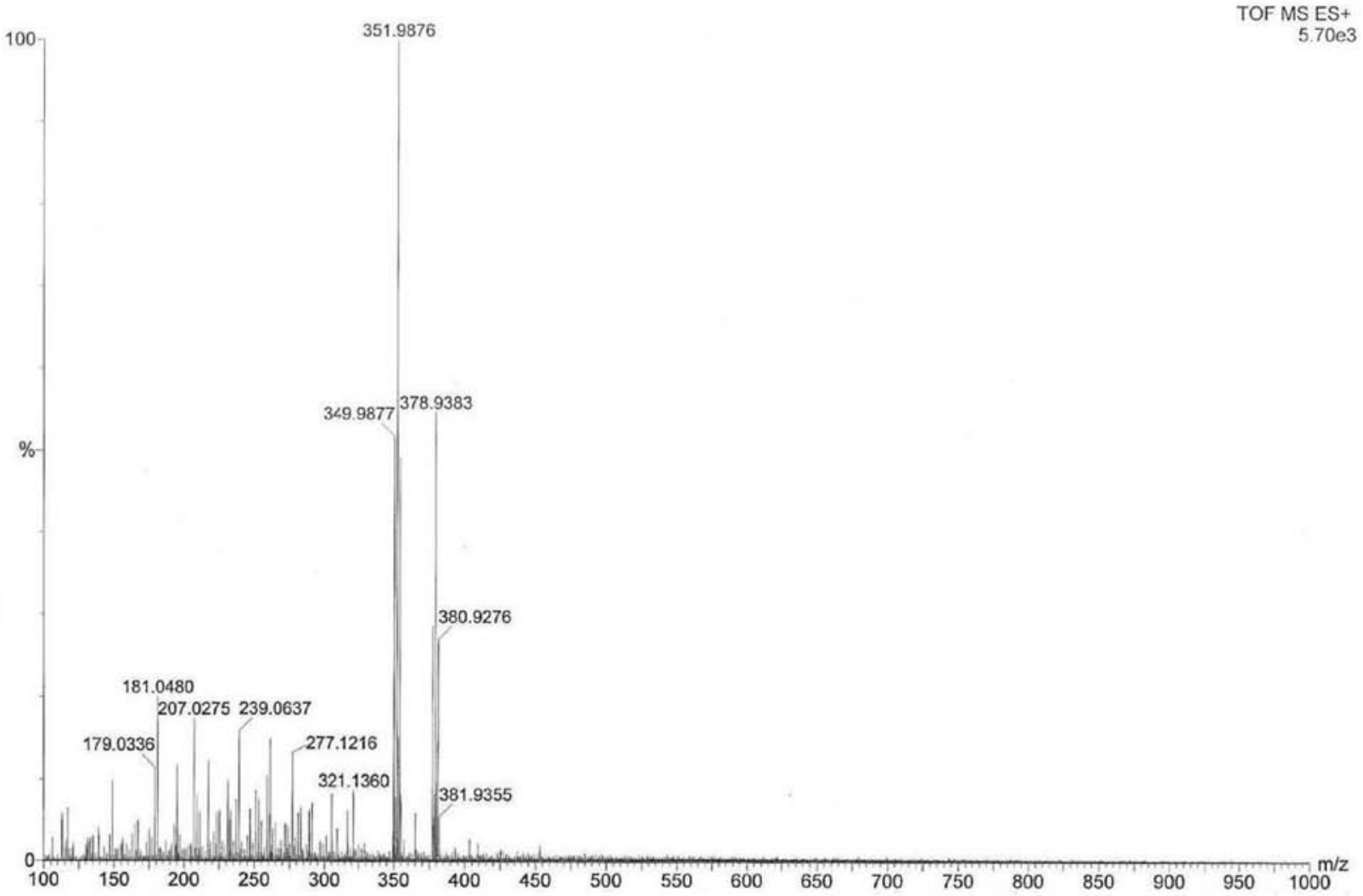

Figure 15S. HRESIMS spectrum of compound 2 
<smiles></smiles>

\section{Relative intensity}<smiles>COc1c(Br)cc(CC[N+](C)(C)C)cc1Br</smiles><smiles>COc1c(Br)cc(CC[N+](C)(C)[Na])cc1Br</smiles>

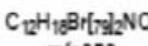

$m / 2350$

1

2

$\mathrm{C}_{12} \mathrm{H}_{18} \mathrm{Br}[\mathrm{si}] \mathrm{Br}\left[\mathrm{g}_{9}\right] \mathrm{NO}$ $m / 2352$

\section{$\mathrm{C}_{12} \mathrm{H}_{18} \mathrm{Br}\left[\mathrm{si}_{2}\right]_{2} \mathrm{NO}$} $m / 2354$<smiles></smiles>

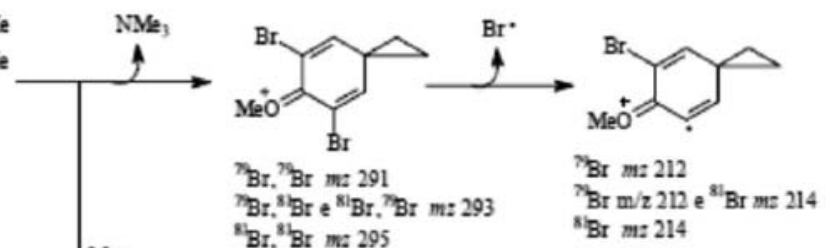

${ }^{8 / B r}$ m: 214<smiles>CCC1(CCF)C=C(Br)C(=O)C(Br)=C1</smiles>

${ }^{7 B r}{ }^{7 B r}$ ma 276

"Br, ${ }^{81}$ e ${ }^{81} \mathrm{Br},{ }^{7} \mathrm{Br} m=278$

${ }^{8} \mathrm{Br},{ }^{8} \mathrm{Br} \mathrm{mz} 280$

Figure 16S. Proposed fragmentation for the molecule of compound 2

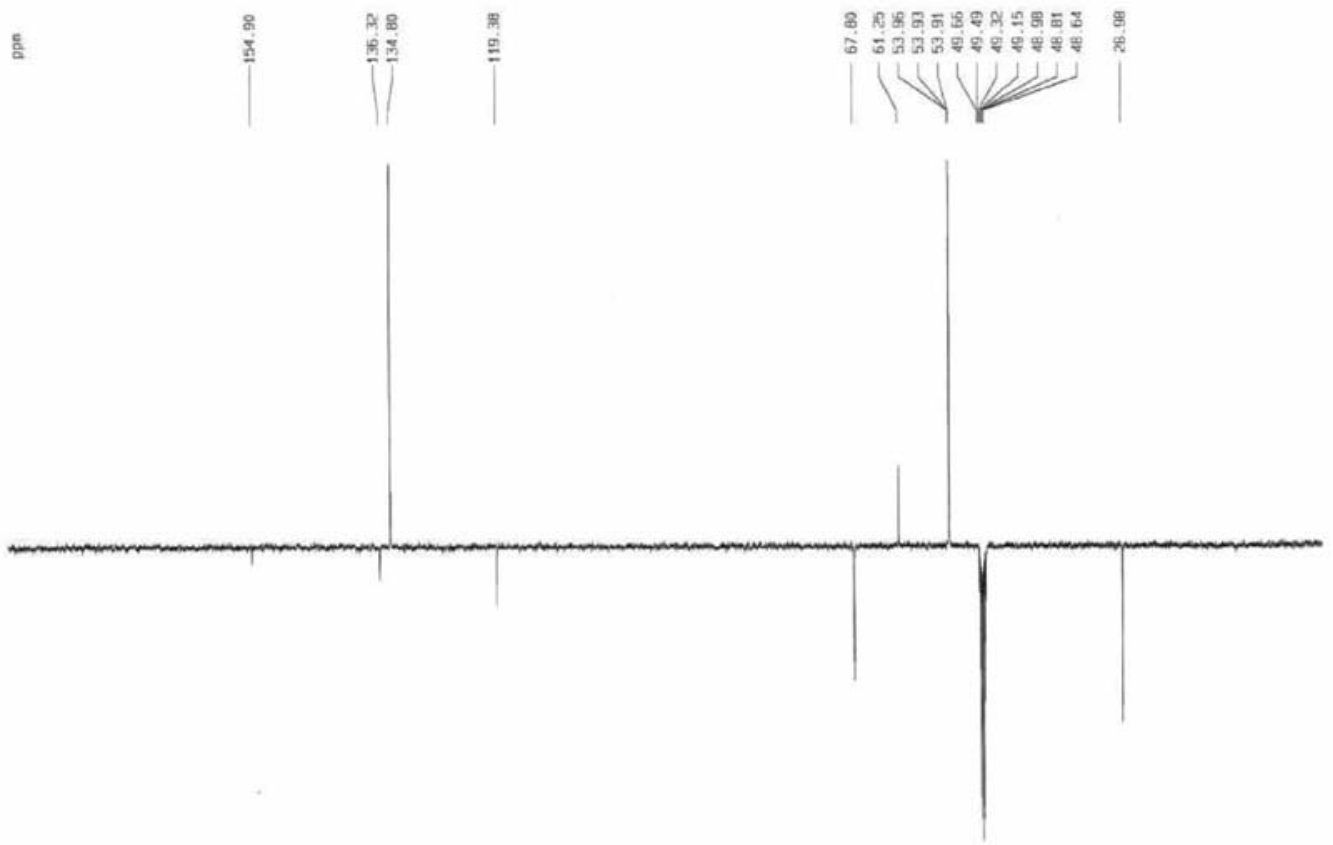


$\mathrm{S} 10$

Lira et al.

Quit. Nova
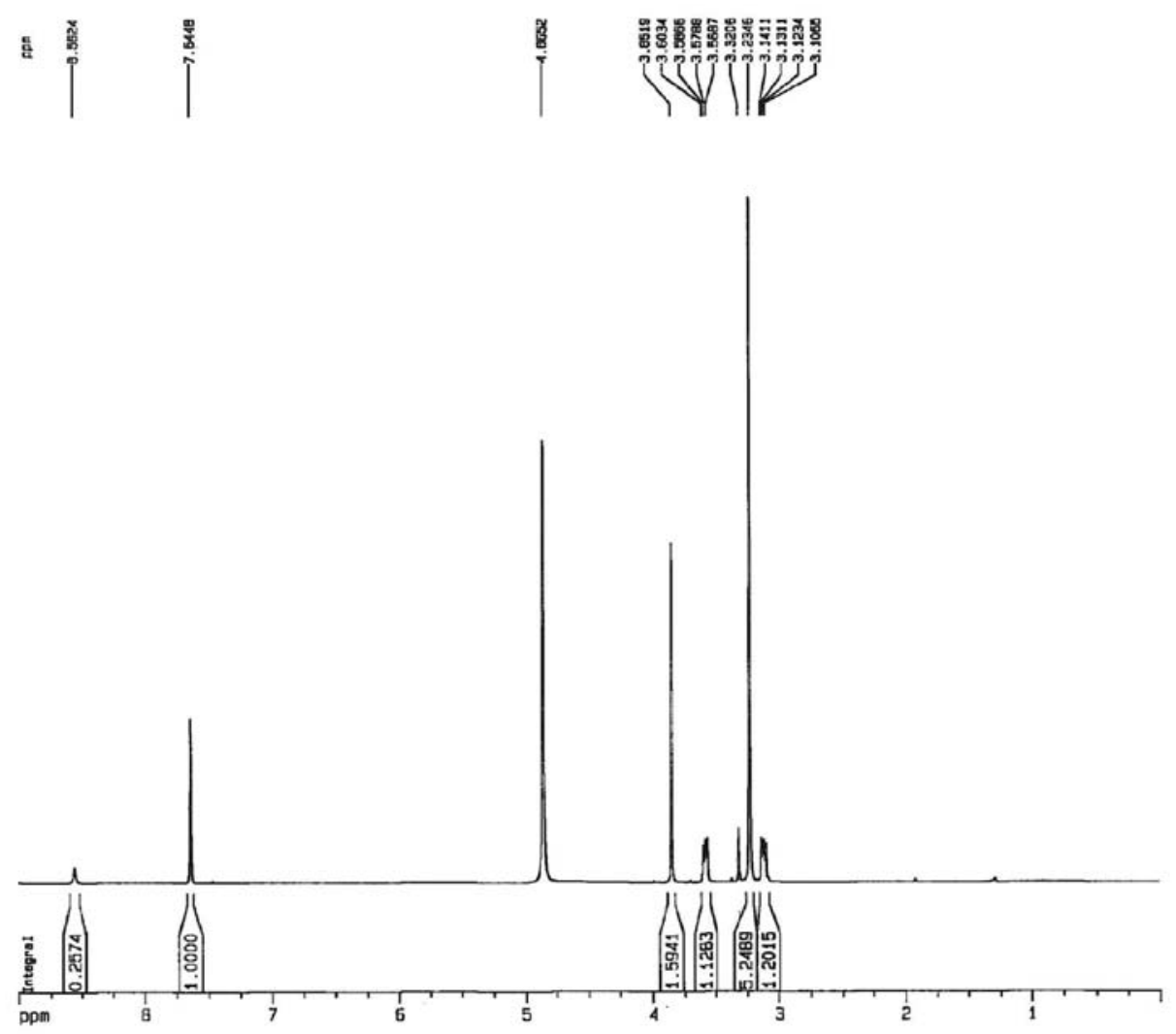

Figure 18S. ${ }^{1} \mathrm{H}$ NMR spectrum data of compound $2\left(C D_{3} \mathrm{OD}, 500 \mathrm{MHz}\right)$
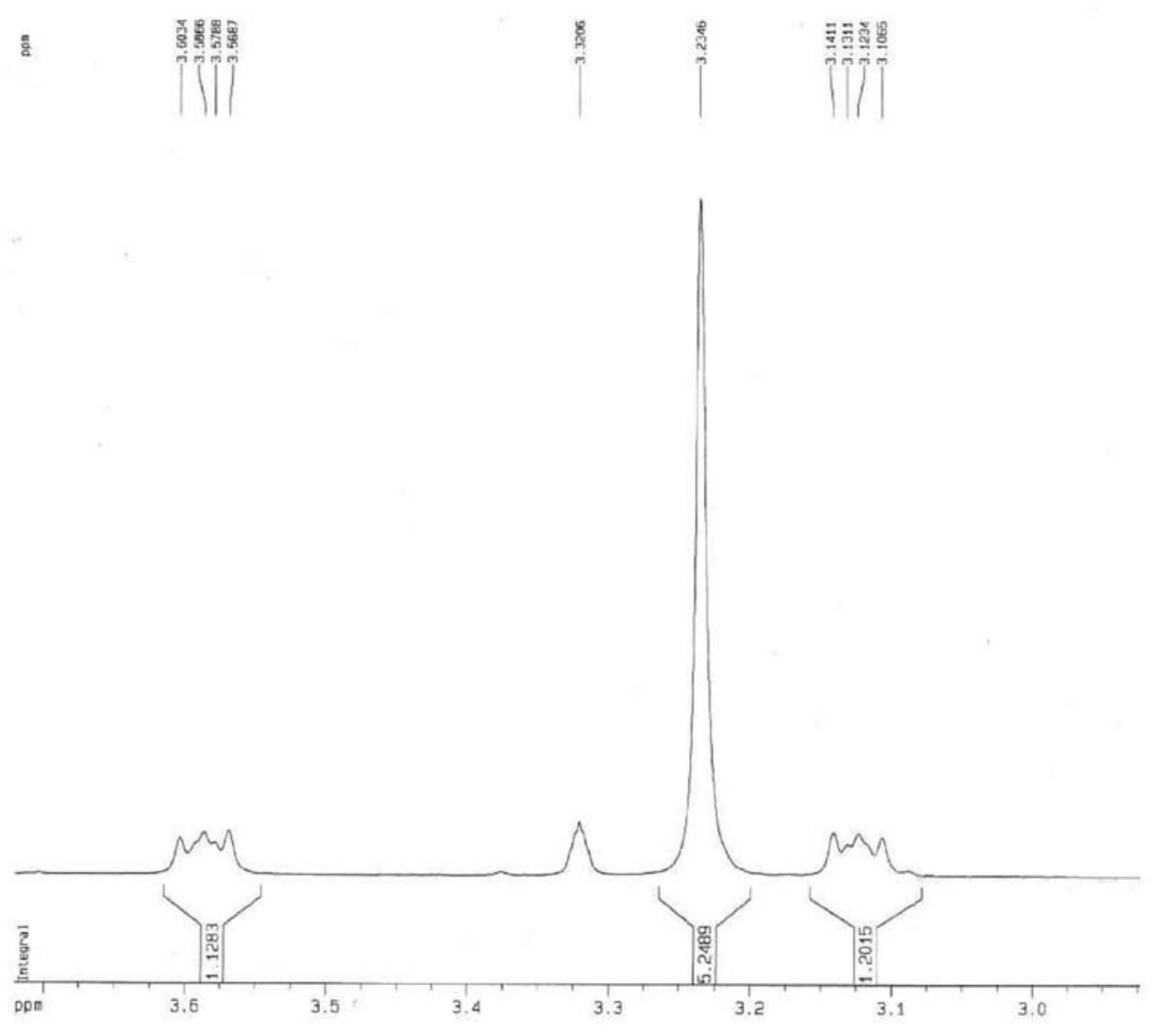

Figure 19S. Expansion of ${ }^{l} \mathrm{H} N M R$ spectrum at the region of 3.0 - 3.6 of compound $2\left(C D_{3} \mathrm{OD}, 500 \mathrm{MHz}\right)$ 


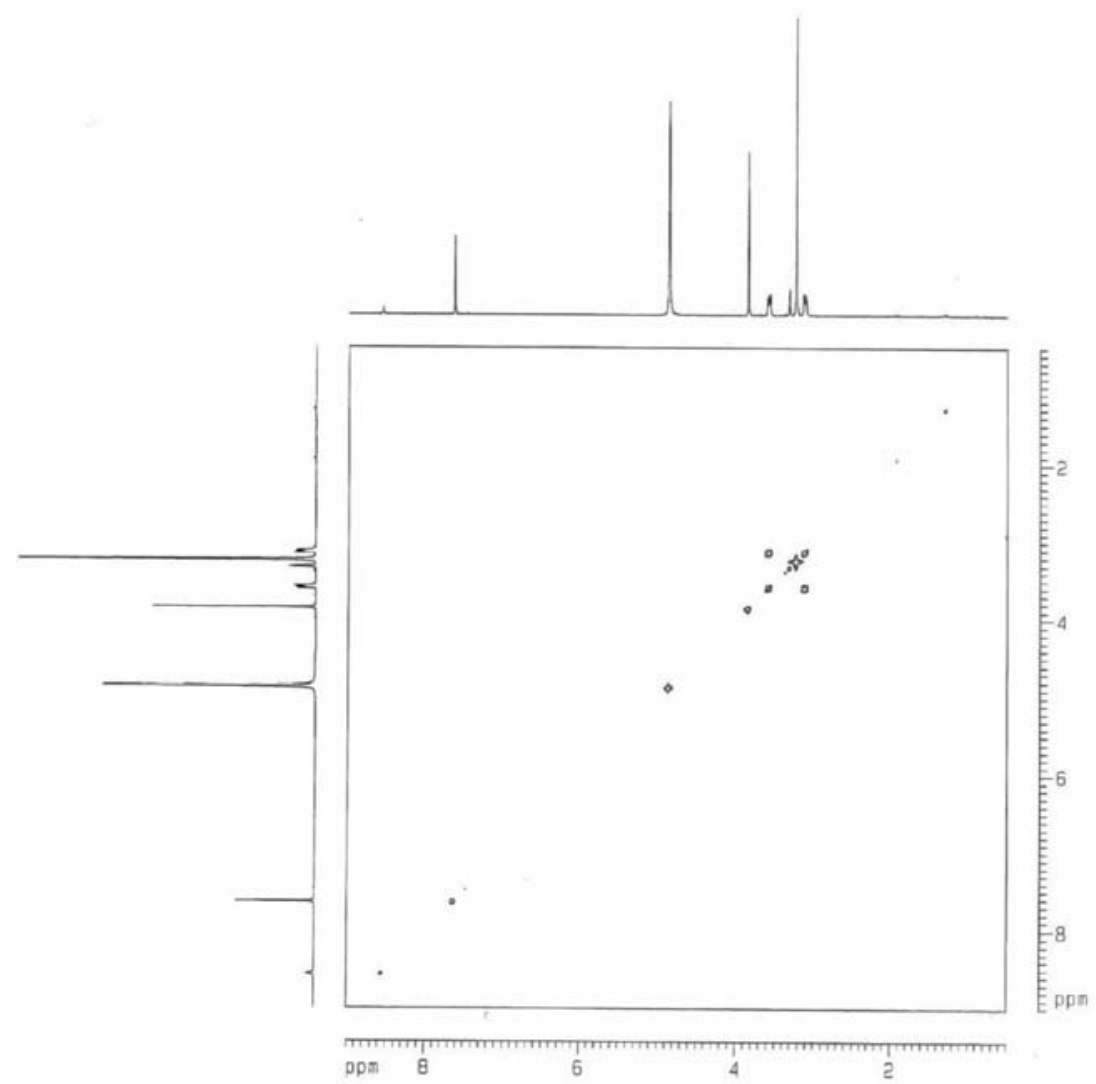

Figure 20S. ${ }^{1} \mathrm{Hx}{ }^{l} \mathrm{H}$-COSY correlation spectrum of compound $2\left(\mathrm{CD}_{3} \mathrm{OD}, 500 \mathrm{MHz}\right)$

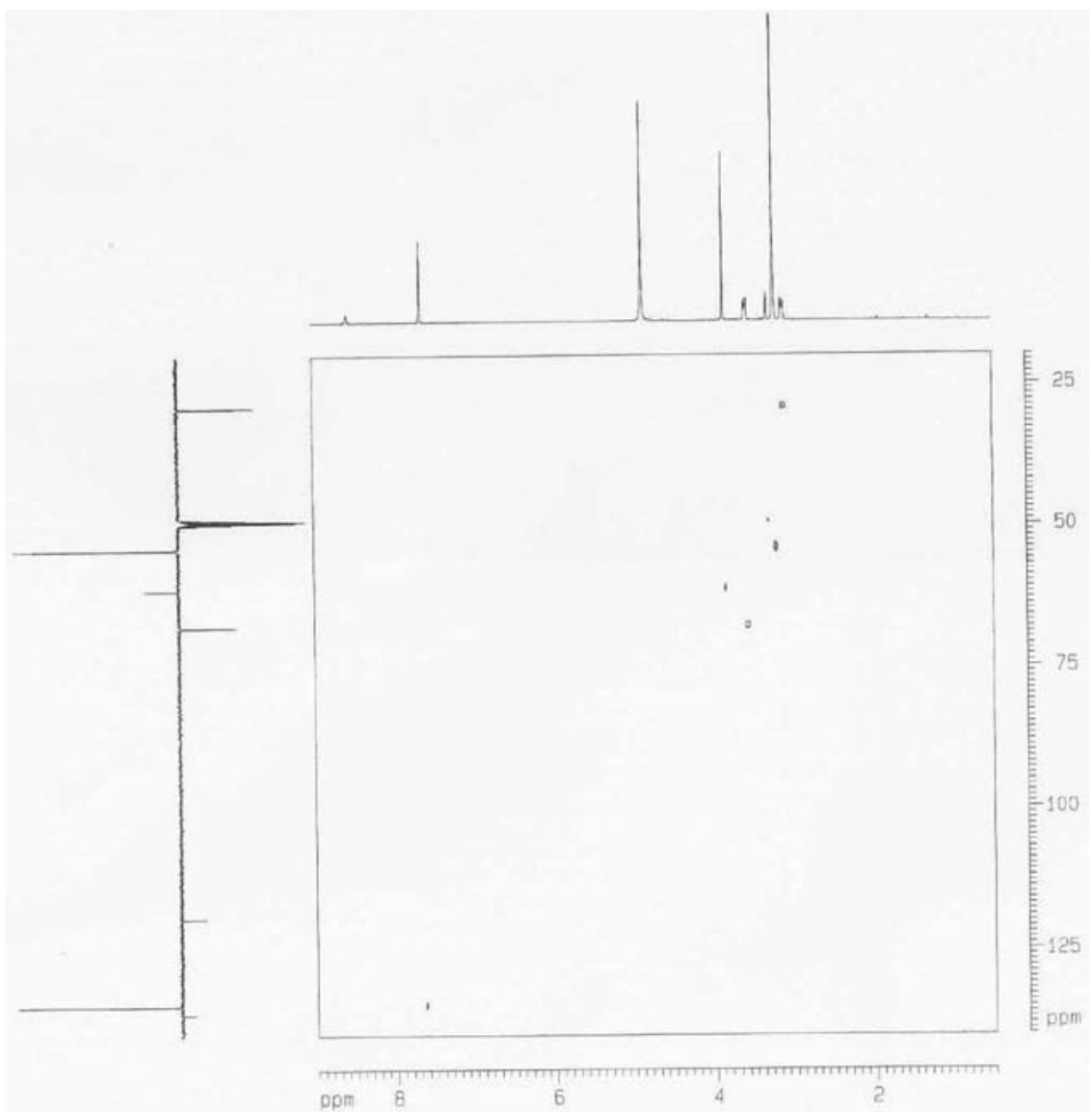

Figure 21S. ${ }^{1} \mathrm{H} x{ }^{13} \mathrm{C}-\mathrm{HMQC}$ correlation spectrum of compound $2\left(\mathrm{CD}_{3} \mathrm{OD}, 500\right.$ and $125 \mathrm{MHz}$ respectively) 


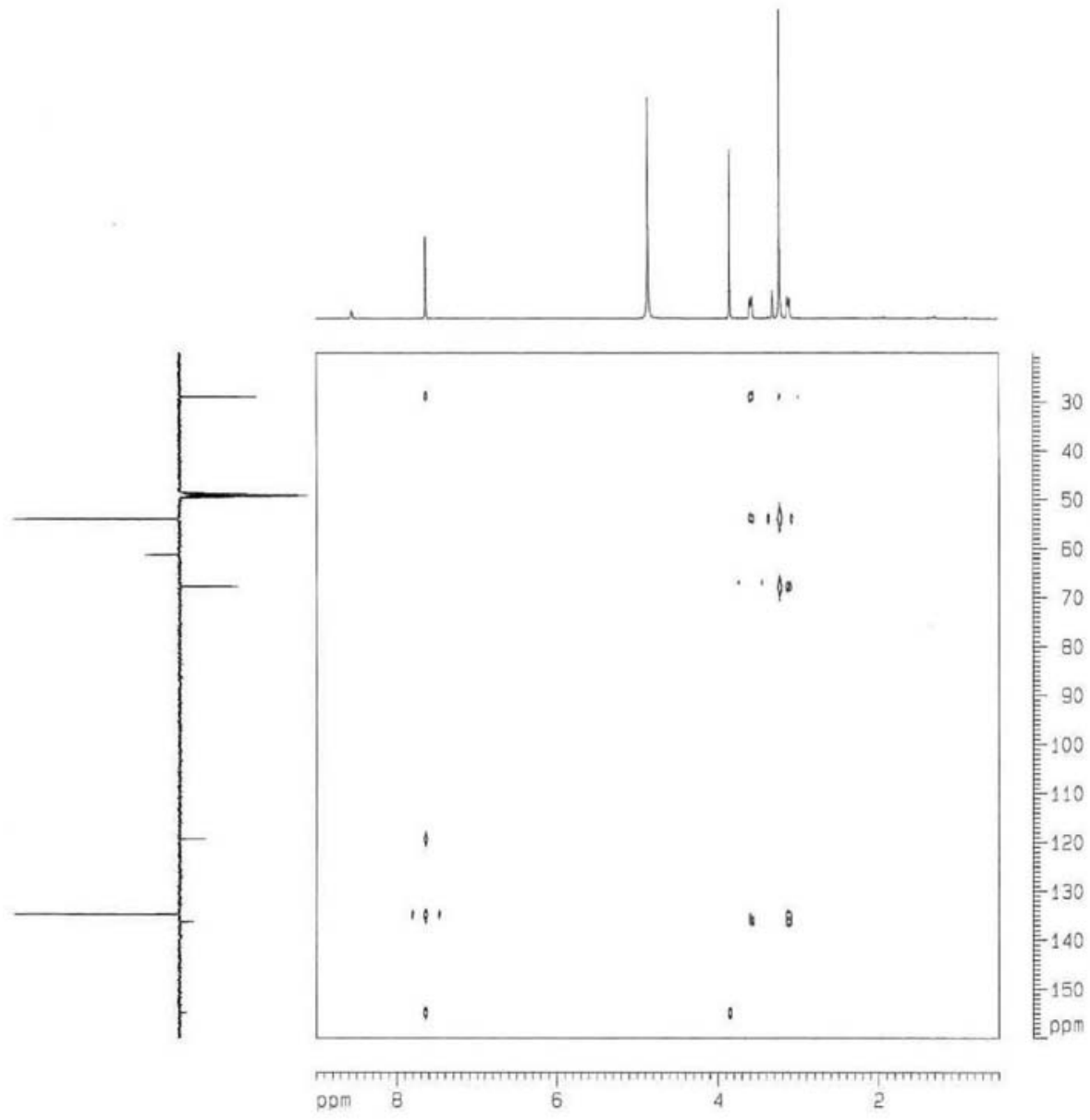

Figure 22S. ${ }^{1} \mathrm{H} x{ }^{13} \mathrm{C}$-HMBC correlation spectrum of compound $2\left(\mathrm{CD}_{3} \mathrm{OD}, 500\right.$ and $125 \mathrm{MHz}$ respectively)

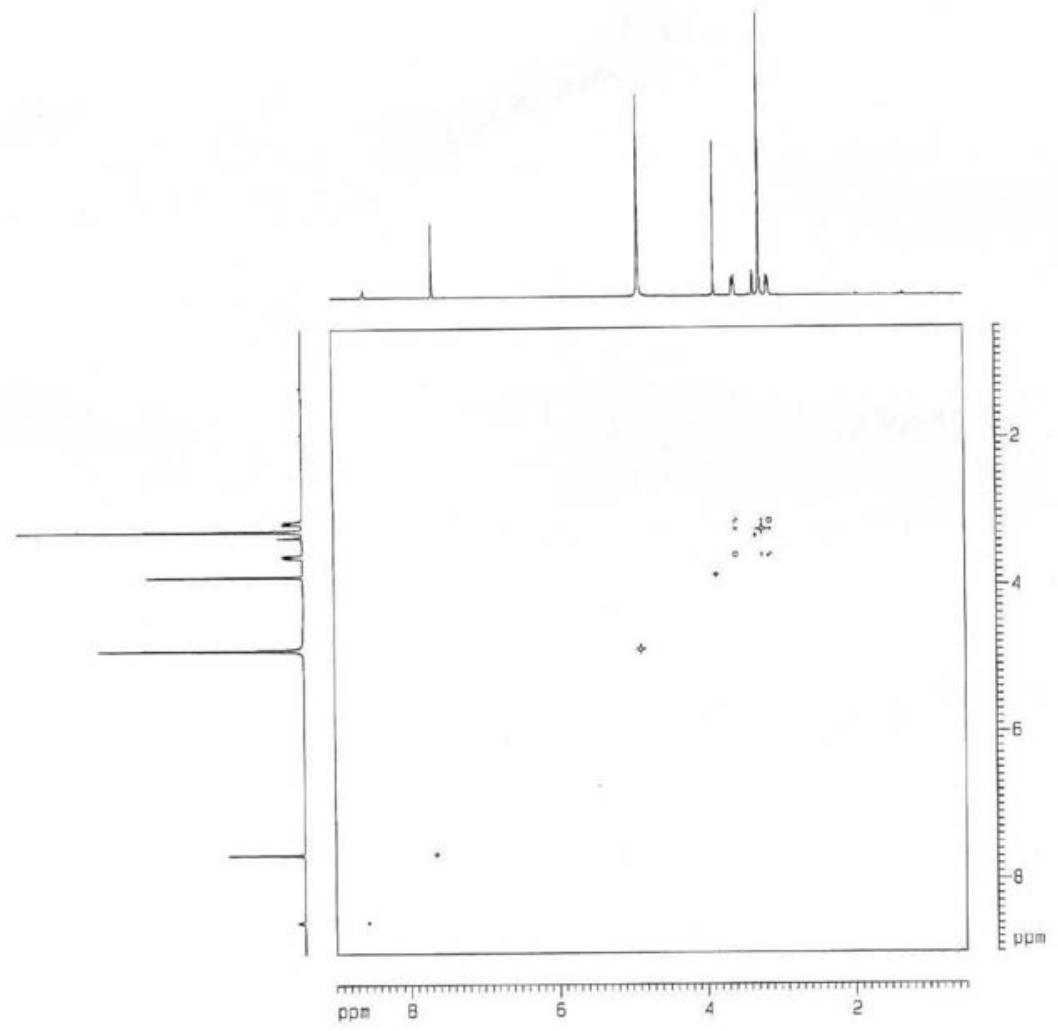

Figure 23S. ${ }^{l} \mathrm{H} x^{l} \mathrm{H}$-NOESY spatial correlation spectrum of compound $2\left(\mathrm{CD}_{3} \mathrm{OD}, 500 \mathrm{MHz}\right)$ 